University of Rhode Island

DigitalCommons@URI

Open Access Master's Theses

1978

\title{
The Effects of Priming and Subliminal Oedipal-Related Stimuli on Competitive Behavior of College Males
}

Katherine C. Haspel

University of Rhode Island

Follow this and additional works at: https://digitalcommons.uri.edu/theses

\section{Recommended Citation}

Haspel, Katherine C., "The Effects of Priming and Subliminal Oedipal-Related Stimuli on Competitive Behavior of College Males" (1978). Open Access Master's Theses. Paper 1569.

https://digitalcommons.uri.edu/theses/1569

This Thesis is brought to you for free and open access by DigitalCommons@URI. It has been accepted for inclusion in Open Access Master's Theses by an authorized administrator of DigitalCommons@URI. For more information, please contact digitalcommons-group@uri.edu. 


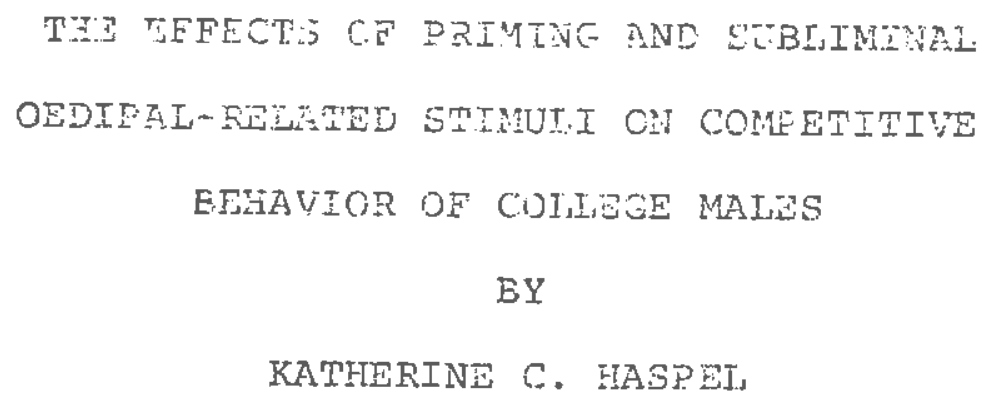

A THESIS SUBMITPED IN PARTIAI FULFILLMENT OF IHE REQUIREMENTS FOR THE DEGREE OF

$$
\text { MASTER OF ARTS }
$$

IN

PSYCHOLOGY 


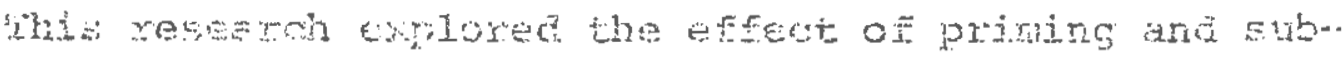

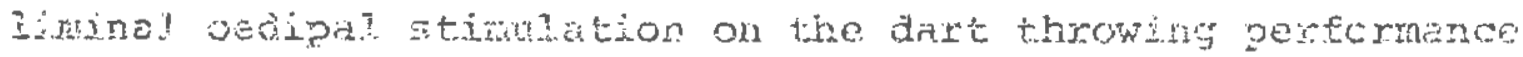
of 35 college mites. The design was simlax to that used by

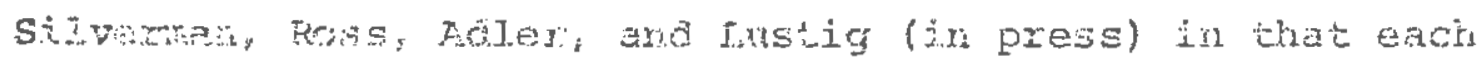
subject was seer individualy and, tn adjition, had ple and pot romburas tokn sor the thee within subject oxperimentel conditione. Eacin vithirabject condition coraisted ot a verbal heseage and a congruent piccure presented at a speeä of 4 mer. one condjtion was designed to enhasce oedipei guilt, ore to decxease it, and ore to serve as a rentzal. rontrol.

Wine 36 swbjects vere divioed into three piiming groupst of 12 snojocts each. One groue, designed as a replacation ox the work cone by sirvernan ef al. (in press), was presentea with both direct arä projective priming matecial designed to arouse oedipal guilt: one group was shown neutiat dirste materiaj and oedifai-releted projestive material; and one group saw neutal materiai anli. It was predicted that the subliratal stimuli would heve the same effect in als three grours.

The data was analyzed with a repeated neasures analysis of covizance. No significant yin ffects or interation eifects of stimug conterit rere fomd. The only significant 
effect energing was an inte....hulu hetween prine and experimenter. In aditition, a priori comparisons cunducted or She full prime replication grom also yielded no significant Iesulis.

The results were discussed Eor their stgrifjcance ir dewonsitrating that if there is an effect of subliminal oedipal stimulation on dart-throwing performance, it is at best a weak one. Questions about both the reliability ard generalizability of the results of the work of Sj.lverman et al. (in press) were raised. 
ACYNOWGEDGWHENTS

7 would like to exprese my gratitude to several people whose help and guidance made this research possjole, nost notabiy Robert Harris, my co-investigator: Dz. James prochaska, my major professor: and Dx. Wayne Velicer, sta.tistirs and design consultant. In adijtion, without the close telephore contact made avajlable by Dr. Isloya Silverman, caiefu? replication would have been impossible.

I monid also like to thank the hard-working experi.montej:s, Paul Cassarino, Paul Gallagher, Cheryl Knasin, Mary Lou Maccarone, and Lori Tartaglia; Dr. Charles Collyer For his help with understanding and working with tachistoscopic stimuli; Bill zwick for his invaluable assistance in the data aralysis; and the rest of my thesis comititee, Dr. A1?an Bextar and Dr. George Fitrelle.

In addition, special help was provided by Dr. Peter Merenda, Dr. Ed Carney, and Pamela Harris with difficult data analysis problens; Dr. Al silversicein provided the neuiral pictures; and Mrs. Grace Garth gid tire excejlent typing.

Finsily, I want to thank my husband. Paul Silver for his patience and support during this trying year. 


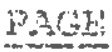

INST OF MAEES . . . . ............ ix

ITSY OE FIGORTS . . . . . . . . . . . . .

INRRODUCMTON . . . . .............. 1

FPTIOR:

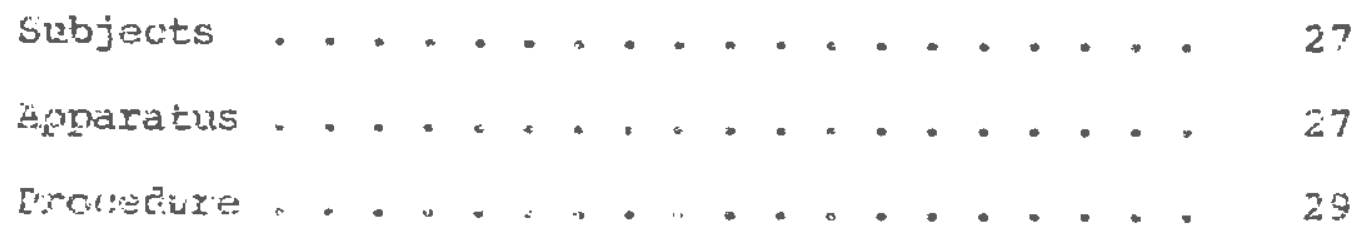

FESOTRE:

Gorell änalysis . . . . . . . . . 35

Test for: Sequence Effect . . . . . . . . 40

Tests on the kodel ............. 40

A Priori Comparisons . . . . . . . . . . 42

viscrimination Task Aralysis . . . . . . . 43

EISOUSEION .................... 44

RIPLRENCT HOTES . . . . . . . . . . . . 53

PEEERUNCES . . . . . . . . . . . . . . 54

AFEENDIX A

Bubliminal stinuli ........... 59 APENDIX B

oedipal Quastionnaire . . . . . . . . . 65 APPENDIX $C$

Dedipal story for Story Recall . . . . . . 55 
7. VETENDIX D

Neutral Questionraire ............ 67 LIPFNDIX E.

Neutral. Story for Story hecall ......... 68 ATPENUIX $T$

Decails of Expeximenter-Subject Interaction . . 69 AI'PFNDIX G

Information About: the Tourmament Experiment . . 71 APPENDIX H

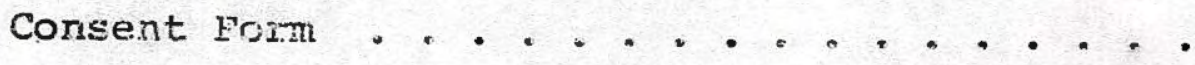

AFPRNDIX T

Discrimination Task Jnstructions . . . . . . ALPENITIX J

Tournament Experiment Debriefing Fom . . . . . 74 APPENDIX K

Feedback Form ................. 77 . IAPQENDIX is

Room Diagram . . . . . . . . . . . . . . 79 APPENDIX M

Means ard Standard Deviations of Bastelirie

Dät Scores . . . . . . . . . . . . 80 AYTENDIX N

Simple Effects Test on Prime by Experimenter Interection .................... AYPENDTY 0

Newman Keuls Test of Prime at Experimenter PC. 
FFYENDIX P

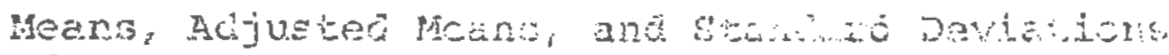

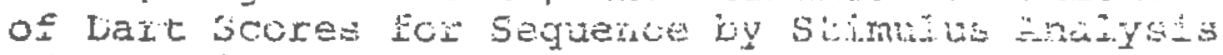

o: Covmiance. . ................. 85

IPFENTIX $Q$

sequence by stimulus Alalysis of covariarce

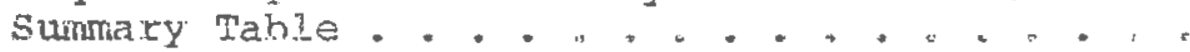

APPENTES R

Siandard Deviations of Dart Sones Collapsed

Ecross Levels of simulus . . . . . , . . . .

APYEHDIX S

Analysis of Variance of Eabeine Da"t Scores

Surmary Table.....................

FPPENDIX T

Actual and Guessed sequence of stimuli in

Six Discrimination Tasks 


\section{I.TST GH THES}

TPISI

PI GE

1. Surdaty of Procecine

2. Heans, Etariard Deviations, and Adjusced Mieans for the Dar scores

I. Aralysis of Covariance Simmary Table fot overall Analysis 


\section{L.ST OF FIGURES}

1. Fizperimenter by Priming Condition Interaction 


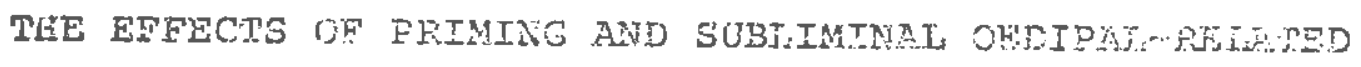

STIMULI OU COMTETITVE BEHAVICF OF COITEGE MAYES

Psychoanalytic theory has been pooriy researciad and is consiöerej by many, both arajysts and non-analyots dilke, to be unrezearchable. While this mey in ject be tarue cf its nctapsycholcgical theory, parts of jte dinical theory 1 end themselves to empizical investigation.

Tle Ejsirinction betweer cinjcal and metapswalogical theories has jeen made by recent peychoanalytic wrifers (E.9., Ftejn, 1976, Schafer, 1976; silverman, 1976). Cijical theory is that part of the theory based on data, $i$.a. materjal from elinical work. Included in it ore both aymic aid genetic propositions. Iynamic propositiors deal. with current unconscious conflicis that are saij to molivate hehavior. Genetic propositions are those which iyoothesize the post cause of the present underlying confiict. An exarnple of a dynanir proposicion is that male nomosexuality i.s motivated (in part) as a defense against uriconscicus incestuois wishes toward one' 3 mother; that is, a sexue? relationship with a woman is unconsciousl.y equated with incest erd is therefore avoiced. i related ganetic proposition is that men who have these strong conflicts over their incestuous wishes are men whose mothers behaved too seauctively toward there when they were chilaren. 
Metapsychological vopositions yo beyone the däta; they can even be viewer as "theomy aivon the theory." Inoluded among then are the construct of drive, energy, id. and ego. Some psychoanalytic withers have ascerted that metapsychological propositions are in fact iressentirs to psychoanalytic theory (e.g., kJejn, 1976). whey axe cer. tainly almost impossible to validate empirically. chirical propositions on the other hand, are more testahie. Fut because even the clirical theoxy deals wi ch uraconscicus processes or past events, convincing empirical support of it has been scant.

Silveman (1976) reports a program of research that claims such support. Specifically, he claims that his sublininal research using syndrome-specific conflictual stimuli has provided convincing evidence tor pychoanalytic theory's dynamic propositions, that is, for the poychoanalytic assumptjon of active unconscious wishes that notivate day-to-day behavior. Psychologists of a psychoanalytic persuasion may welcome his work as convincing support, while those of a non-analytic orientation wjll probably be more skeptical. Given the debate that his research is likely to stirulate, it is important that sorie of sj.lverman's most central procedures be repilicated in independent laboratories.

Fron a reacilng of silveman's (i976) most recent review axticle in American Psychologist his woxk seerns difficult to refute. As ore looks more clonely at the original research, however, it becomes apparent that his 
reaults are neither as stroing nor as alean nethociologically as his 1976 paper would sugyest. A inore critical review is in oxdex.

\$ilverman and his associates began approximately 13 yeors ago to investigate psychoanalytic hypotheses using tachisioscopic presentations of what were hypothesized to be wish-related stjnuli. Although the largest body of this veseerch was conducted with schizophrenics, other groups studied include depressives, stuttexers, male homosexuals, whese people, phobics, and normal college students and hospital employees. Psychoanalytic hypotheses relating to both the intensifjcation of pathology and to its reduction have been investigated; the former have been tested only in laboratory situations, but the latter both in the laboratory and in actual interventions.

The general procedure for pathology intensification is as follows: subjects are seen for a number of sessions in which both baseline and critical measures of their pathology are taken. (Measures used have included the Rorschach, adjective check Iists, and observations of pathological nonverbal behavior.) In between these measures the subjects look into a tachistoscope and are shown conflictual or neutral verbal and/or pictorial stimuli exposed for 4 milliseconds. In addition, before the baseline measure of pathology is taken, subjects are shown neutral tachistoscopic presentations. This practice is to ensure that the two measures of pathology are made under comparable conditions. The experimenter interacting with the subject is always bina as to 
what stimulus is in the tachistoscope. it should a s.5o be noted that in some of his work, in adoition to the A-msec exposure of the stimilus, Silverman also showed subjects the same stinulus supraliminally, that is, for 20 seconds. This exposure tended not to increass pathology in the way that the subliminal exposure did; but, as will be shown later. contrary to Silverman's assertion in his $19 \%$ teview some supraliminal effects were found $(e .9 .$, Cox; 1974; Rustein \& Golaberger, 1973).

The analogue pathology-reducijon paradigm is similar, the only aifference being that subjects are shown stimuli hypothesized to reduce rather than increase thej.r pathology. Pathology-reduction work designed to have a lasting effect has involved subjects' viewing certain subliminal stimuli repeatediy over time. As the research proposed herein inciudes both pathology intensification and recuction, a dis.cussion of each aspect of Silverman's work wilil be taken in its tum. We will aiscuss his work with peychiatric populations and then his research using norral subjects.

By far Silverman's largest body of cata concerns pathology intensification in male schizophrenics (Lomangino, 1969; Moriarty, 1968; Silverman, 1966, 1971; Silverman \& Candell. 1970; Silverman, Candel1, Pettit, \& Blum, 1971; Silverman \& Silverman, 1967; Silverman \& Spiro, 1967a, 1968; Silverman, Spiro, Weisberg, \& Cande11, 1969; Spiro \& Silvernan, 1969). The major hyoothesis tested has been that schizophrenia lcalled by Silverman and his assciciates, "primary process ego pathology") is motivated at least in 
vart by confi.cte over agcressive pishes, specifically that schizophrenic symptoms are a defense against these wishes. The selevant symotoms incluke both jisturbances in thinking anci in nonverba? behavior which make the subject appear to otrers to be iliogical, loose, inappropriate, and strange. This hypothesis was tested by presenting schizophranic: subjects an aggressjve stinulus and comparing their change scores in this session with change scores in another session in which a neutral stimulus was presented. Various verbal and pictorial aggressive and neviral stimuli were used. For example, a picture of a tiger chasing a monkey was compared to a picture of a bird alighting (Silverman, $1966)$; a picture of a man with a dagger was compared to a picture of a man reading (Silverman \& Silverman, 1967); a picture of a man about to stab a woman accompanied by the words "destroy mother" was compered to a picture of two men facing each other with bland looking expressions accompanied by the verbal message "men talking" (Siiverman et al., 1969). Dependent variables included pathological thinking as neasured by a story recall task, a wora association task, and Rorschach-type ink blots, and an observational measure of pathological nonverbal. behavior. Significant differences vere found in all but one of the studies isilverman, Candeli, Pettit, \& Blum, 1971) on at least one of the neasures used; that is, on at least one of the dependent variables, schizophrenic subjects showed a greater ircrease in pathology when exposed to a subliminai aggressive stimulus than when shown a reutral stimulus. In studies involving schizophrenics 
hompitelized for longer peace of the, significant differences on nore measures vere tound (Sijvecman, 1971).

Another variable menipulated with schizophrenic subjects was the arousal of libinjnal wishes with a libininal stinujus (a picture of a bixom rade woman). Blthough tris Et.inulus was found to lead to a decrease in efficiency on istelisgence test-iype questions, ih did not lead to an incxase in egn pathology as measuren by patnological thinking and pathological nonverbal bet:avior (silverman \& Silverthan, 1957$)$.

Four studies also looked at the effect of a supraIininal exposture of an aggressive stimulu's (Jomangino, 1969; Moriarty, 1968; Silverman \& Candeli, 1970; Silverman \& Spiro, 1968). In three studies no significant differences were found when the supraliminal condition was compared to either a suclimiral neut.jal condition (Lomangino, 1969; Silvermar \& spiro, 1968) or a supraliminal neutral condition (Silverman \& Cardell, 1970). In addition, Silverman \& Spiro (1968) found a significant difference between the subliminal and supraliminal aggressive conaitions in the same direction as the difference between the subliminal aggressive and neutral conditions (i.e., the subijminal agressive stimulus increased. pathology significantly more than a supraliminal presentation of the same stimulus). On the other hand, Moriarty (1968) founa a decrease in the efficiency of schizophrenics on an arithmetic task after the presentation of a supraliminal agressive stimuius.

Two important drawbacks of silverman's work on 
pathology intensiflcation with schizonnenics should be roted. Fixst, the entire body of research has been conducted usjng only male subjects, thereby limiting generalizability. Second, except for the Lomangino (1969) and Moriarty (1968) sturies, ali analyses reported consist only of a series of t. tests, even when multivariate techniques (e.g., Hoteliing's $2^{2}$, analysis of variarce, analysis of covariance, multivaxiate analysis of variance) are nore appropriate (i.e., when more than two conditions and/or more than one dependent variable are involved).

Iess extensive research has been carried out with stutteiess (Silverman, Xlinger, Lustbader, Farrell, \& Martin, 1572) and with male homosexuals (Si\}.veman, Kwawer, Walitzky, \& Coron, 1973). Two psychoanalytic hypotheses were investigated vith stutterers: (1) that stuttering will increase when oral aggressive wishes are aroused by a picture of a roaxing lion, and (2) that stuttering will. increase when anal wishes are aroused by a picture of a dog defecating. Both stimuli. lea to significantly more stuttering on a paraphrase task than did a neutral stimulus. As pilot work showed no significant differences between a supralininai presentation of either conflict stimulus and a subiliminal neutral stimuius, no sturaliminal condition was used in the study.

Two groups of male homosexuals not in psychotherapy vere studied, the second study being a replication of results founa on a post hoc basis in the first. The hypothesis investigated was that a subliminally presented incestuous stimulus would irstease the homosexuals' scores in the direction of 
horusexuality on a sexual fodules assassment. The stimulus used was a picture of a nude man and woman ix a sexualiy suggestive pose accompanied by the vewi.i ressage "fuck monny." The sexual feelings assessmen: consistea of ratings of pictures of ten males and ten fiemales. A froup of heterosesual males was included for comparison puxposes in the secona siudy. The hypothesis was upheld. No aifferences between the incestuous and control conditions vere found for the heterosexual maies.

Although Silveman (1976) incicates that his work with depressives produced strong support for the psychoanalytic theory of depression, closer look at that work shows the results to be more equivocaj. The hypothesis investigated was that depressive symptons are motivated by a conflict over aggressive wishes. Stinuli presented were similax to the stimuli used with schizophrenics. In one study female hospitalized depressives were found to show a greater increase in depression after an aggressive stimulus than after a neutral stimulus (Rustein \& Golaberger, 1973). Depression was measured by an adjective check list. However, this result was not upheld on replication (Silverman, Bronstein, \& Mendelsohn, 1976).

In another study of hospitalized depressed patients, this time males, Cox (1974), using four analyses of variance, found significant results in the predicted direction only for psychotic patients and only on one of his five variables (i.e., an increase in intropunitive responses on a measure of direction of aggression). In addition, both of these 
studies found changes whon c thpraliminal aggressive condithon was compared to the neutra 2 condition. Cox found gsychotic depressives to decrease intopunitive responses in these sessions. Similarly, Rustein and Goldberger found an increase in outward eggression as measured by the Rorschach in their supraliminal condition. ndaitional problens exist in the two other stuaies of depressives cited by silverman in his review article (Miller, 1974; Varga, 1974). These were conducted with nonpsychiatric populations. Varga (1974) studied coliege studeniss prescreened for depressive trends. Although he found a significant drop in their hypomania scores after the presentation of a subjiminal aggressive stimulus, all other significant reavits he reports were found on ineasures combined on a post hoc basjs. In addition, his hypomania scale was derived by separating the depressive from the hypomanic adjectives of the Wultiple Affect Adjective Check List depression scale, which he presented as a 50-point scale rather than as a check list. Both of these procedures were likely to have reduced the validity of this scale.

At first glance Miller's (1974) results appear quite impressive, as she reports significant differences on several measures between her depressed and nondepressed groups. However, upon closer examination, che sees her overall analyses of covariance found only one interaction effect on one dependent variable. Her multiple significant results were produced by her follow-up (Duncar's range) tests. These shoula have been conducted onIy after simple effects tests 
were done for the significant interaction effect and only for that paricular intevaction. In audition, Duncan's range tests probably coucain too much likelihood of Type I exror fi.e., rejscting the null hypotiesis wher it is in fart cruel. Mhis makes it even more clear that Si.jermin's inappropriate use of mutiple $t$ tests may have had the elfect of fincing significant differences when there in fact were nore.

Another imporiant aspect of Silverman and his associates' work on pathology intensification should be mentioned. Is it could be argued that any conflictual stimulus coulo axouse any pathology, silverman et a1. (1976) investigatea the question of the specificity of the relationship of each pathology to the stimulus used to increase its manifestations. To do so they replicated the work with all four diagrostic categories studied. They showed subjects two conflictual stimuli, one that had increased the pathology in an earlier study and one that had increased the pathology of subjects in arother diagnostic category. For no group did the "unreiated" stimuius lead to an increase in the specific pathology (it should be noted, however, that for the depressed subjects in this study, neither did the "related" aggressive stimulus).

In addition to studying the pathology intensifying effects of subliminal stimuli, Silverman and his associates investigated the ability of such stimuli to temporarily reduce pathology. As is the case with their work on pathoiogy incensification, the largest body of work 
investigating pathology acuction hat been conducted with male schizophrenics iBronstein, i977; kaye, 1975; Silverman \&. Candell, 1970; Silverman, Candeli, pettit, \& Blum, 1971; Silverman, Levinson, Menälsohn, Ungaro, a Eronstein, 1975; Silverman, Pettit, \& Durne, 1971, Silverman et al., 1969).

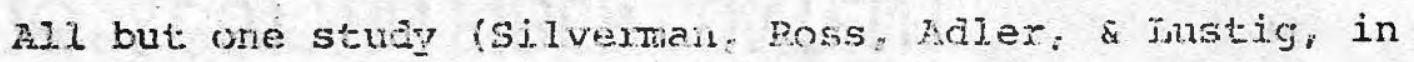
press) has investigated only the pathology-reducing effect of some sort of symbiotic stinulus. Most are laboratory studies investigating the termorary effect of the stimulus on narifestations of pathology, but a few have investigated the long term effects of the presentation of a pathology" reducing stimulus over time fParker, cited in Silverman, Note 1; Silverman et al., 1975; Silverman, Frank, \& Dachinger, 1974; Silveman, Martin, Ungaro, \& Mendelsohn, Note 2).

The laboratory work with male schizophrenics used the subliminal symbiotic verbal message "mommy and I are one," sometimes accompanied by a pj.cture of a man and woman with the boundaries between them indistinct. This stimulus was found to lead to a decrease in pathological thinking and/or pathological nonverbal behavior for those schizophrenics relatively differentiated from their mothers (as measured by an adjective check list). It was also found to lead to a decrease in self-object differentiation (Sjlverman, Candeli, Pettit, \& Blum, 1971; Silvernan, Pettit, \& Dunne, 1971). Further stuaies found that no other symbiotic stimulus (e.g., "mominy and I are the same," Bronstein, 1977) had the sane pathology-reducing effect, except "my girl. and I are one" 
(Kaye, 1975), which had an even qreatter efroot than the "mommy and I are one" message. Eor feicele schirophrenics, who were used as subjects in only one etudy, "daddy and $\tilde{i}$ are ore," rather than "momny and I are one, "had a pathology reäxing effect (Cohen, cited in silverman, in pressi) One study investigated the effect of a suphalininal symbiotic stimulus on pathology reduction and found no differences between this and a supraliminal neutral stimulus isilverman \& Candell, 1970). However, no comparison of the supraliminal symbiotic with either the sublininal symbiotic or the sublinirial neutral condition are reported.

Another group for whom the laboratury effect or the symbjotic stimulus was investigated was male honosexuals (Silverman et al., 1973). The scores of these subjects on a Rorschach threat index decreased after the presentation of the symbiotic stimulus.

0ither work with the symbiotic stimulus has investi-gated its effect. when used as part of a treatment procedure. One of the first groups with whom this was attempted was schizophrenics, who were shown either the syrbiotic or a neutral. stimulus three times a week for six weeks along with other treatment (silvernan et al., 1.975). When the $t$ values for the eight dependent variables were pooled and transformed into a $\mathrm{x}^{2}$ function, a significant difference between the groups was found. This procedure was illegitimate, however, as one shoula not combine results from different dependent measures in this way. The original \pm tests yielded significant differences on only one measure (self concept). 


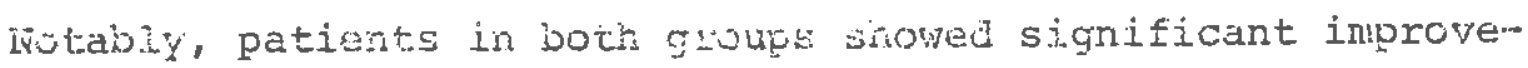
ment on six of the measures.

When used insteac of relaxation in a syatematic desensitizaticn paradiga with insect phobics, the symbiotic stimulus was found to iead to significantly more improvenent tinan a neutra1 stimulus (Silverman et al., 1974). Measures Enowing this cifference were a behaviotal avoicance test and the experimentex's rating of anxiety. No comparison between the symbiotic stimulus and relaxation itself has been made.

Two studies were conducted involving the behaviorai treatiuent of obese women (Silverman et al, ijote 2). During thsix: weekly treatment sessions, half of the subjects in each study were shown the subliminal symbiotic stimulus and half were shown a neut.ral stimulus. No between group aifferences wexe found at the end of 8 (Study 1) or 12 (Study 2) weeks of ireatment. However, subjects who were shown the sublininal symbiotic stimulus silowed significantly greater weight loss at a 4-week follow-up than did subjects shown the neutral stimulus. This difference was maintained with the one group of subjects (Stuaj 2) also seen at an 8-week foIlow-up.

Two major objections to Silverman's work have been raised in the literature. The first takes issue with the ethics of SiIvemman's experiments and'the second with the interpretation of his data.

The ethics of his procedures have been criticized primarily in studies designed to increase subjects" patholagy (Lasser, 1977). Silveman (Note 1) has been able to 
answer these ethical questwhe whth the following data:

When the control session has followed the experimental session by one to three ways, no aifiurences even approaching sigrificance have been folnd between the two baseline measurements of the subjects' vathology. (2) one study measured pathology twice, first intuediately after the presentation of the subliminal stimuli and agair 1.5 to 30 minutes later (Silvernan, Candell, Pettit, \& Blum, Note 3 ). Notably, the significant change firom baseline to the first eritical measurement was not found when the baseline was compared to the second critical measurement.

Guthrie and wiener (1966) and wiener and kleespies (1968) have offered an alternative explanation of Silvernan's results. They suggest that his data is obtained as a resuit of supraliminal structural information ("partial cues") available to the subjects under supposedly subliminal conditions. Using stimuli from an earlier study of subliminal registration (Eagle, 1.959), Guthrie and Wiener (1966) demonstrated that: (1) angularity in and of itself is per.ceirred by subjects as negative; (2) Eagle's aggressive stimulus was more angular than was his benevolent stirulus; and (3) in an experiment comparing subliminal stimuli differing in both angularity and aggressive content masked by a supraliminal neutral stimulus, suojects rated the nelutral stimuils more negatively after the argular, but not after the aggressive, preceeding stimulus.

Silverman and spiro ( $1967 \mathrm{~b}$ ) countered by testing their own aggressive stimuli for angularity versus curvedness. 
They djo this both at the cmpon gization used by Guthrie and wiener i.e., at ils ajuatirs there the subject first reported secing somethisg) and at inz inration uf the presentation of stimuli in their ow wcre (ì.e, $4 \mathrm{msec}$. Six different pairings of aggressive and neutzal simini were shown. Fine three signjficant cisferences found on the angularity-curved dimension were in the direction of the neutral stimulus being more angular or the aggressive being more curved. Wiener and Rleespies (1968) then argue that it could be a cue other than angularity that leads to $\operatorname{silverman}^{3} \mathrm{~s}$ results. Howevet, the consistency of silverman and his associates" findings using a large number of different stinuli make this hypothesis difficult to support.

The other argunent Silverman and Spiro (1957b) and Silverman (1.968) use ir support of the subliminality of their. stimili is the results of thejr kiscrimination task. This task was administered in most studies, always after the experimental manipulations. It was sypically conducted in one of two ways: (I) Subjects were shown two stimuli at the 4 -msec exposure and told that one was $\bar{A}$ end one was $B$; they were then shown $A$ and $B$ in a ranjom order ten times and usially given a monetary incentive to tell. which was which. (2) Or subjects were shown ten 4-msec exposures of two different stimuli in a raridom order and given a monetary incentive for telling whether each stimulus was the same as or djfferent from the one immediately preceeding it. In their most recent work silverman et al. (in press) used 20 trial.s in this task. Silverman (i976) jeports that over 
S0: of his subjects cinnot d...scligguish at better than a chance level $(p<.10)$ ore stimulus from another. Moreover, he states that the results supporting his hypotheses are not dependent on the smali group of subjects who do discriminate. Although this data is inpressive, there ere problens with both the cesign of Silverman's discriminatjon task and the analysis of his results. The fact that subjects were usually given only ten triels means that even at the ..20 significance level a subject must get at: least eight for only tiwo) correct trials in order to be considered able to discriminate. In addition, the procedure of showing the stimuii singly in random order is problematical because the subject does not view the stimuli. he is discriminating between on each trial. Finally, power is reduced in silverman's analysis because each individual's resuits are viewed separately. Combining the data of all subjects with a non-parametric statistical technique may have been able to detect discrimination that Silverman missed. In addition to criticisms Silverman has received in the literature, other drawbacks of his work with psychiatric populations has been roted above. A surmary of some of them is in order: (1) Most of the work has been conducted only with male subjects, thereby liniting generalizability; measures of pathology tended to be constructed by the researchers themselves (e.g., sexual feelings assessnent) and/or to be of questionabie reliability and validity (e.g., the Rorschach); and (3) inappropriate andior too-liberal (i.e., too much chance of Type I sxror) data analyses tended 
to de used.

Silvexman and his aszociates have attempted to correct Whe latter two criticisus in their botter designed work with nomal subjects, thereby making this work both more difficult to rerute and nore deserving of repilation. The most imuressive study to date has been one conoucted by silvernan, foss, Aciler, and lustig (in press) who investigated oedipal conpetitive feelings in four groups of male college students. The dependent variable was a behavioral measure of dart throwing ability, and mulcivariate analysis techniques were applied to the data. Subjects in three of the groups were foland to increase their dart throwing performance when shown the subliminal verbal message "beating daa is $0 . \mathrm{k} . "$ in sequence with a picture of a younger and an older man, both smiling: they decreased their performance when shown the snsssage "beating dad is wrong" in sequence with a picture of the same two men frowning.

The procedure involved showing each subject all stimuli in one session, jn counterbalancea order, continualiy taking baseline and eritical measures of dart throwing. All cata were analyzeä using an analysis of covariance followed by Duncan's range tests. The first study found that both the WRONe and the oK stimuli differed significantly in the predicted directions from a neutral stimulus $(p<.001)$. Two symbiotic stimuli ("mommy anc I are one" and "daddy and I are one") were not found to differ significantly from the neutral stimulus. The second study found the WRONG and the OR stimili to differ significantly from each other (p<.001), 
but ondy the wrovg atimiliz so dutfer from the neutral (p<.01). No significant differences for the symbiotic measnge ("romp and I are one") pere found.

A thire study was conducted, which did not find significant differences anong the conditions at all. However, the stinuli in this study were shown at considerably higher iliwaination levels than in the previous two dart studies. A fourth study was then conducted to see if it: was indeed the higher illumination levels that led to the lack of significart findings; therefore, two groups of subjects were used, each shown the stimuli at different illumiration levels. A sjgnificant stimulus by group interaction was found on an analysis of covariance. When followed by andiyses of covariance for the groups separately, only for the low illumination group was a significant effect founa. As ir the first two stuaies, the WRONG and OK means were found to differ significantly from each other (p<.005), but this time only the ox mean differed significantly from the control $(p<.05)$. Again, no significant differences for the symbiotj.c stimulus ("rommy and I are one") were obtained. The major drawback of this study and, in fact, of most of silverman and his associates' work with normal populations, vias that all subjects were "primed" prior to the presentation of the subliminal stinuli. Theoretically this practice was to "trigger" derivatives of whatever conflict was being studied at the time. This priming has always included a stocy recail task using a story related to the particulax confict bejing studied (e.g., studies of students judged to be prone 
to depression used an aggreijite puine; Miller, 1974; vargä, 1.974). Silverman (1965) and Miller (1974) assert that the prining triggers drive Gerjvatives aj,eady active in the subject. They say it is necessary with nomal subjects because, unlike psychiatric subjects, normal people are not continually internally stimulated by chese conflicts.

The common practice of using prining grew from the results of Silverman's (1965) study, which was designed to see if aggressive stimuli could lead to an increase in manifestations of ego pathology in male hospital. employees. Results in the predicted airection were found only for subjects primed with an aggressive passage. Although an eariter study using male college students did find results without priming (Silverman \& Silverman, 1964), Silveman's 1965 results have been used as a justification for nost later priming.

There are several difficulties with such a justification. First, Silvernan's (1965) study was methodologically weak. He saw 25 of an original 32 subjects in an unprimed condition before he thought of using a prime; when the hypothesized results were found for only the ? primed subjects, Silverman added 45 more subjects, jll of whom he primed. In addition, he did not get the predicted results on his primary variable (pathological thinking) for the entire group of primed subjects. He therefore removed from the group 9 subjects who were found to have had aggressive associations to the control stimulus; it was only without. these subjects that the difference in pathological thinking 
between the control and expertiental sessions reached significance. He also founa, on a post boc basis, that only those primed subjects who had a relatively por ability to neutrailze aggression (as measured by their baseline Rorschachs) shower a significant difference between experinental anc control sessions.

The difference between the unprined subjects' change scores in the experinental and control sessions were found to approach sigrificance $(p=.06)$ in the direction opposite to that predicted (i.e., pathological thinking increased more in the control than in the aggressive session). This was noither dealt with adequately by Silvernan (1965), nor was an atternt at replication made.

The replication study does not even use an unprimed group (Silverman \& Goldweber, 1966). Rather, it concentrates on investigating the supraliminal-sublininal question wich normal subjects and on replicating Silvarman's finding that it is only with poor neutralizers that an aggressive subliminal stimulus has an effect. The supraiiminal results are equivocal and show another use to which priming has been put. It was only aftex a post hoc analysis, exciuding those subjects rated as deniers of aggression (based on their recall of the priming passage), that the difference between the subliminal aggressive and supraliminal aggressive conditions reached significance. The hypothesis that the subliminal effect would be observea only in poor neutralizers was upheld. It should be noted, hovever, that people who have difficulty neutralizing aggression can be viewed as a 
particular "pathologjcal" suriciou of a normal population. Even if one accepts the necessity of priming in order to increase pathological thinking in (a subgronp of) a normal population, it could be thet schjaphrenic-nike ego pathology is such an extreme symptom that normals must be primed for it. to appear. It is possible that less severe symptons and more comon conflicts covla be aroused witnout using a prime. Silverman anc Silverman's (1964) study is a point in fact. The conflictual stimulus they used was the torso of a nude female; the dependent variable was an increase or decrease in certain Rorschach content categories. Significant differences between experimental and control conditions were found without priming. In addition, Golland (1967) corducted a study of female college students, oniy half of whom were pximed. He used an aggressive sublinitral stimulus and the dependent variable of Rorschach aggression-subject scores. Golland reports that priming "was not a necessary cordition of the aggressive subliminal. effect, although it might heip to make the effect more observable (p. 4123)."

Besides work studying ego pathology in hospital employees (Silverman, 1965; Silverman \& Colldweber, 1966). priming was used with normal subjects in investigations of defensiveness (Golland, 1967) creativity (Anteli, 1970); with prescreened subjects judged to be prone to particular conflicts in studies of the female castration complex (E1lman, 1971), avoidance of success (Cherry, cited in Silverman et a.., in press), and aepression (Killex, 1974; Varga, 1974). 
whe only work with rormal abjects that aid not use a prime at ali was a study investigating pathology reduction rather than intensicicatior (Parder, cited in Silverman, Noie 2). Notably, significant results were found. College siudints who were shom either the symbiotic stimulus "roma and $I$ are one" or the verbal message "pros and $i$ are ong" four times a week for six weeks received higher grades than students shown a neutral stimuius. It is theresore clear that although the practice of priming normal subjects has become routine, the necessity of doing so has not been demonstrated. Whether consistent subliminal effects can be found without priming is in need of further investigation. Justification for the use of priming has included. reference to earlier subliminal work in which a greater subliminal effect (as measured by recall and/or recognition of associates to the subliminally presented word "cheese") was found in cases of food deprivation (Spence \& Ehrenberg, 1964); food deprivation plus "set" (i.e., reading a story about food, Gordion s spence, 1956); and "sect" alone (i.e., preseritation of the word in a setting filled with a cheese odor, Gadlin \& Fiss, 1.967). Psychoanalytic drives are therefore made analogous to the hunger arive; i.e., both are considered to be something internal to all people, which carn be "triggered" with the use of appropriate stimili. Aleernate explanations for the effect of a prime have not been irvestigatea. Wiener and Kleespies (1968) suggest that the prime could indjcate to the subjects the results the experimenter is seeking, However, silverman's finding 
of within subject differsncar, aisng with the results of ins Aiscrimination task, weakens this argument. But it roula bo that, rather than puil on woflidts actady existing in the subjects, priming creates a "pathology" which is then affec:ed by the subliminal stirulj. Whether priming triggers something internal or imposes something external remins open to question.

The dart study, because of i.t.s use of two differerit kinds of priming material, lenäs itself to an investigation of the priring question. One type of priming materiai used in the dart study explicitly dealt with competitive and/or. oedipal feelings, and one was designed to tap these feeijngs in an indirect way. Included in the Former was a story recall task and a questionnaire about competition and the subject's motier and father. The more jndizect primes were a Rorschach cara (Card IV) and two TAT Catas (6EM and 7BM), chosen Eor their hypothesized tendencies to "pull" mateital related to the mother and father and therefore to tap oedipal conflicts. Whereas cne could argue that the story recall and questionnaire could create a conflict in the subjects that could then lead to susceptibility to cedipal-related subliminal stimulation, that argument wolid be more difficult to make if the subjects saw only the projective test cards. If the projective measures were the only prime, silverman's assertion that priming is only stirring up conflicts already there would be more aifficult to refute. And, of course, ift Giiverman and his associates' results could be obtained without the use ot priming at ali, the existence of unconscious 
wishes tapped by sublininal sutwit- nould be even more strongly suppoxted. On the other hand, if Silvernan's xesults can on $I y$ be obtaines using ali of his priming maturiai, they could be interpreted as resulting from something put into the subject's mina that was not there to begin with. His interpretation of his data using normal subjects, then, in spite of its good methodology, would be left open to serious question.

The study to be described investigated the question of the effect of priming. Specifically, Silverman's dartthrowing study was replicated under the following conditions: (1) using ail of the conflict-related priming material silyerman and his associates used in their work; (2) using Silverman's projective priming material and other neutral material; and (3) using only neutral priming material. only the stimuli showing significant differences in previous research were used (i.e., "beating dad is wrong," "beating dad is $0 . k_{.}$, " "people are walking").

Silverman et al., (in press) and silverman (in press) offer a clear explanation for the choice of these stimuli based on the psychoanalytic postulate of the oedipal conflict. As a boy differentiates himself from his mother and sees her as an external object, he directs his sexual impulses toward her. At the same time that these impulses are doomed to be largely ungratified, it becomes clear to the boy that his father is receiving the gratification denied to him. This leads the boy to experience competitive and hostile feelings toward his father. Fear of his father's retaliation, the 
Ferception of hi.s nother as a taboo object, and the boy's loving feelings towards his father all lead him to defend against both his sexual wishes for his mother and his aggressive impulses toward his father. Both of these impalizes, as veil as the defenses against ther, are active in ail males to a grsater or lesser degree depending or how well the oedipal conflict has been resolved. Fsychoanaiytic waiters have posited that they can interfere with conpetitive pexfomance (e.g., Beirser, 1961). This is because of the uncorscious equation of winning wish cefeating the fatrer for the mother's love, which the boy both does and does not wont to do. What the subitininel. messages in the arart study do is side with one side or the other of this conflict, by ejther sanctionirg ("bating dad is $0 . k . "$ ) or condeming ("beating ad is wrong") the idea of defeating the father in ocupetivion.

This stuãy also ingiuded a discrimination task to check on the subiiminality of the stimuli. The task was somewhat different in design from the one Silverman used in order to increase the possibility of finding discrimination if it is there. Subjects vere given 20 discrimination trials and on each trial were shown both of the stinuli to be discriminated.

\section{Predictions}

As discussed above, the necessity of adminiscering a prime before the presentation of subliminai stimuli has not been cleariy demonstrated. In addition, psychoanalytic theory hypothesizes that the oedipal confict is present to a creater 
or lesser degree in ail. peopie. The subitininal stimuli were designed to tap this crnflict in one of two ways. The WRONG stimulus was designed to condem the iciea of defeating the father in conpetition, whereas the OK stimulus was desigred to sanction this iaea. The third stinujus was a control.

The following was therefore predicted:

(1) The WRong stimulus would decrease subjects' dart scores relative to the control stimulus.

(2) The ok stimulus would increase subjects' dart scores relative to the control stimulus.

(3) The above two effects would be observed under all three priraing conditions. 
METHOLS

\section{Subjects}

Subjects were 36 me 3 undergraduates ranounly seiscted from volunteers Eron two introductory psychology doumeds. Students in one course recetved extra usit for participation An this study; siudents in the other filfilled a cour requirement by aring so. Aay student who wore tintsed giasses $^{i}$ or who grew up in a home where Engitish was rot the primary language spoken ${ }^{2}$ was not ussd in the study * whe subjects ranged ir age from 18 to 29 with a mode of 19 ard a mean of 19.5. Each was rameonly assigned to ore of the three treatment groups.

\section{Apparatus}

The apcaratus nere designed to be 2.5 close to those used iy silverman et al. (in press) as possible.

All subjects were exposed to three experinentzl conditions, each one involving the tachistoscopic presertation or a different pair of verbal and pictorial stimuli. The stimuli were as exact copies of Gilverman et al. "s as

IEIIJerman (Note 4) repurts that tinted glasses change the contrast of the siinulus field in the tachistoscope.

${ }^{2}$ silvermar et al. (in gress) report finging that sub-

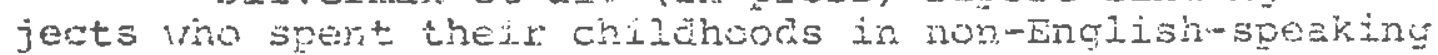
homes do not. show the same responses to treylish vereal sub linina? mesages that native Engigh speakirg eubjects do. 
possible. The critical venbil stimij. were (1) DEATING DAD I.S WRONG; (2) BEATING WAD IS $0 . K_{-i}$ (3) DEOPIE ARTE WALKING, each printed in biack ink ard occupying two lines on a white card.

The critical pictorial stjmuli were J.ine drawings intended to be congruent with the verbal nessaues. For stimulus 1, the picture consisted of a drawing of an older and a younger man looking at each other with their lips turned down, designed to protray oedipal guilt. For stimulus 2, the picture was identical except that the lips were turned up, portraying oedipal approval. For stimulus 3 , the picture consisted of two biand-looking mer situated next to each other so that they could be seen as walking.

These stimuli were shown through an elcctronically controlled two-field tachistoscope. The exposures of both verbal message and picture were for $4 \mathrm{msec}$, and each was shown four times from the same field. Betireen exposures the subject saw a blank fieid wich went off each time the stimulus field went on. After beirg given the instructions "ready, set" the picture came on for $4 \mathrm{msec}$ followed by the blank field for $5 \mathrm{sec}$, followed by the instructions "ready, set" and the verbal stimulus for $4 \mathrm{msec}$, followed by the blank field for another $5 \mathrm{sec}$. This sequence was repeated four times.

The tachistoscopic illumination levels were set to be 5 Iootlamberts for the stimulus field and 15 footlamberts for the blaik field. The room lighting was set at 15 footlamberts. In adaition, wjth pilot sukjests, it was deternined 
that (1) a flicker or flash of light was ciearly visible when each stimuius was exposed and $(2)$ the filckers made by one stimulus were not distinguishable from those made by another.

The other apparatus used were four inetal pointed darts and an American style dart board, consisting of seven concentric circles with the bull.'s-eye marked 100 and the others radiating progressively from the center marked 80 , $60,40,20$, and 10 respectively. The dart board was hung on the wall 98 inches from the throwing line, with the bottorn of the aart board 58 inches from the rloor,

\section{Procecure}

Except. for the different prime conditions, the proceaure was designed to be as close to that of silverman et al. (in press) as possible.

The content of the priming material was an independent variable. Subjects were randomly divided into three groups, each of which was administered different priming material before the presentation of the subliminal stimuli.

(1) Full prime group. This group was given the same priming material used by Silverman et al. It included, in the following order: (1) a lo-item questionnaire involving guestions about competition, mother, and father;

Rorschach c.rd IV (the so-called father card); (3) TA'T cards $7 D M$ anc $6 \mathrm{BM}$ (usually viewed as depicting a father-son scene and $a$ nother-son scene respectiveiy); and (4) a story recall task administered while $S$ was still viewing cara $6 \mathrm{BM}$, after 
he had told his own story.

(2) Partial prime group. Whe priming for this group included: (1) a neutral interest:s questionnaire consisting of nodified items from the strong vocational Interests Blank (Campbe11, 1974); (2) Rorschach card IV; (3) SAT cards 7BM and $6 \mathrm{BM} ;$ and (4) a story recall task using a neutral story based on one used in previous research (Milier, 1973, p. 51), again read while $S$ was looking at card 6BM after he had told his own story. The story usea by Miller was lengthened asing stateinents from the Encyclopedia Americana (1.965) in order to be of approximately the same length as the oedipal. contilict story.

(3) Neutral prime group. Before subliminal stimulation this group was given: (1) the neutral interests questionnaire; (2) Rorechach card $v$, chosen for its tendency to puld. for a popular response (Exner, 1974); (3) two photographs previousiy rated as indifferent (Silverstein, 1966); and (4) the neutral story recall task, administered after $S$ had told his own story about the second photograph, while he was silil looking at that photograph.

Three different male experimenters were used for this study, each of whom saw four subjects in each treatment condition. The experimenters were $\mathrm{BH}$, age 29, a graduate student.in experimental psychology; PG, age 37, an undergraduate psychology major; ard PC, age 31, a graduate student in clinical psychology. Only PC had been previously trained in the administration of projectives and only $P C$ was a proponent of psychoanalytic theory. 
When $S$ arrived $\mathrm{E}$ Eirs, asieu hin to read an explanation of the study and to sign a coisent form. S was told that he would be particizatido in a dact throwing toumanent in which cash prizes would be awarded. He was told that one purpose of the experincut vas to see if dart throwing ability could be affected by subliminal stimulation and that he would be informed about the content of the stimuji after the experiment was over.

E then administered the priming material appropriate for each group. After $s$ completed the priming materiai, he took eight practice dart throws and was then put through the three subliminal treatment conditions in the same session. Each consisted of a baseline assessment of dart: throwing ability in which $S$ threw eight darts at the dart-board (four at a time with the subject retrieving the first set of darts so that he could throw the second $s \in t$ ). This was followed. by the subiiminal preseritation of one of the three pairs of stimuli already described. S then threw eight more darts in the manner described above. This was followed by the other conditions, in which pre and post assessments of dart throwing ability were again made.

As baseline dart throws were intended to serve in part as buffers (i.e., to absorb the impact of the prior critical condition before the next one was introduced), and in order for all dart throws to be conducted under comparable conditions, the baseline throws were also preceeded by tachistosccpic exposures.

The stimuli. for these "baseline" exposures were neutral 
simuli diffexent from the control timulus. I'iey vere presented in the following oxdez: (I) DEOWIZ ARE IOOKING in sequenve with a picture of two biand-1ooking men facing out from the page; (2) PEOPLF AFE THINKIKG in sequence with a aifferent picture of two bland-looking men facing out from the page; and (3) PEOPLE ARE STANDING in sequence with a picture of two bland-icoking men facjug each other.

While the sequerce of baseline conditions remained Iixed for ali subjects, the presentations of the critical stimuli were counterbaianced. As there are sjx possible sequences in which the critical stimuli could be shown, each sequence was shown to two subjects in each group. A summary of the procedure appears in Table 1 .

Stimuil were inserted into the tachistoscope without E's knowledge of the content. This was done by code colors on the back of the stimulus cards that were arranged in the correct order by someone else.

During S's dart throws $E$ sat in a chair rear the dart board and recorded the number of the circle in which each dart landed. S's score for each baseline and critical dart throwing series was the total of these numbers for the eight throws.

At the end of the session a discrimination task was administered to each $S$ in order to check for the subliminality of the stimuli. This task was admjnistered by one of four female experimenters who were introdured to the subject for the first time at this point. Sach $S$ was given 20 trials in which, under the same conditions as existed during the 


\section{TABIE 1.}

\section{Summary of Procedure}

1) Introauction

2) Priming procedures

3) 8 practice dart throws

4) Baseline I stimulation (PEOPLE ARE LOOKING)

5) 8 Baseline I dart throws

6) Critical I stimulation ( $1 / 3$ of $\mathrm{Ss}$ receive each of 3 "critical" stimuli)

7) 8 Critical J. dart throws

8) Baseline II stimulation (PEOPLE ARE THINKING)

9) 8 Baseline II dart throws

10) Critical II stimulation (counterbalanced sequence)

11) 8 Critical II dart throws

12) Baseline III stimulation (PEOPLE ARE STANDING)

13) 8 Baseline III dart throws

14) Critical III stimulation (counterbalanced sequence)

15) 8 Critical III dart throws

16) Discrimination task

17) Debriefing 
experiment proper, he was asked to try to distinguish the flickers wade by one stimulus from those made by another. He was told that the $s$ who could discriminate best would receive a cash prize. Before the 20 experimental trials each $S$ was shown one message-picture stimulus identified as $P$ and another one identified as $B$. In each of the following trials $A$ and $B$ wexe presented in random order and $S$ was asked to say whether A appeared first or secona. As there are three possible stimulus pairs and two orders of each pair, six different discriminations wexe administered, four to six subjects each, one to five, and one to seven.

After the discrimination task, $s$ was told that at the end of the semester someone would come to his class and pass out an explanation of the exact messages shown and the hypotheses of the experiment. He was told that we would prefer to wait until everyone had been run through the study before revealing the content of the subliminal stimuli. If an $S$ had insisted on knowing immediately what the stimuli were, he would have been toid and asked to keep their content a secret. No subject insisted on knowing the content at this point.

At the end of the semester a debriefing form was handed out to the subjects. In addition to a detailed explanation of the stimuli content and experimental hypotheses, it included an offer to the subject to make personal contact should he feel any lingering negative effects from the experiment ox should he have any questions. No subject did so. The debriefing note also announced the prize winners, who received their cash prizes in the rnail. 


\section{RESUTIS}

\section{Dverz]? Analysis}

A three-way analysis of covariance with one repeated factor was carried ovt or the critical aart scores, with the baseline scores serving as the covarjate. There ware three levels of each factor. The two ron-repeated faciors were pribing condition (full, partial, and neutral) ard experimenter (BH, $P G$, and $P C$ ). The repeated factor was stimuius content (neutral, OK, and WRONG). Tie covariate was repeated under each level of the repeat:ex tactor. There vere four subjects per cell. Mears, standard deviatıons, and adjusted means of all cells are presented in Table 2.

The three-way (prine by experimenter by stimulus) analysis of covariance yielded no significant ( $p<.05$ ) main effects or interaction effects of stimulus content (see Table 3). Moreover, the $\underline{F}$-values of these effects were all less than 1.00. In addition, no signifjcant main effect of priming group ror of experimenter were found. The only significant effect energing was an interaction between prime and experimenter.

simcle effects tests were pexformed in order to interpret the significant interaction. A significant difference was found batineen the prining groups for the experimenter $P C(F(2,26)=A, 4 \pm ; p<.05)$. No significant difference 
TABIE 2

Mears, Standaid Deriations, and Adjusted heans for the Dart scores

Part I. Full prime (PI)

Experimenter $\mathrm{BH}$ (E1)

Content

Neutral (SI)

OR (S2)

Wrong (53)

$\bar{X}$
SD (adj.)

510.00

57.74

435.00

172.92

455.00

508.32

433.32

111.21

449.44

Experimenter PG (E2)

\begin{tabular}{lrrr}
\hline Conient & Neutral (SI) & OK (S2) & Wrong (S3) \\
\hline $\bar{X}$ & 447.50 & 440.00 & 455.00 \\
SD & 89.95 & 60.55 & 68.56 \\
$\bar{X}($ adj.) & 466.54 & 437.03 & 441.67 \\
\hline
\end{tabular}

Experimenter PC (E3)

\begin{tabular}{llrr}
\hline Content & Neutral (S1) & OK (S2) & Wrong (S3) \\
\hline $\bar{X}$ & 542.50 & 555.00 & 540.00 \\
ED & 100.79 & 19.15 & 58.88 \\
$\bar{X}$ (adj.) & 499.38 & 530.01 & 533.14 \\
\hline
\end{tabular}


TAELE 2

Nexs, Stardãd Deviations, and

sojusted hearis for the part scores

Fart II. Partial Prime (F2)

Esperimenter $\mathrm{BH}$ (EI)

\begin{tabular}{lrrr}
\hline Content & Neaträ (S1) & OK (S2) & Wrong (S3) \\
\hline $\bar{X}$ & 430.00 & 525.00 & 537.50 \\
SD & 187.44 & 50.00 & 75.88 \\
$\bar{X}(a d)$. & 469.76 & 532.39 & 560.43 \\
\hline
\end{tabular}

Experirenter PG (E2)

\begin{tabular}{|c|c|c|c|}
\hline Content & Neuteral (SI) & OK (S2) & Frong (53) \\
\hline $\begin{array}{l}\bar{X} \\
\overline{S D}_{\bar{X}}(a d j \cdot)\end{array}$ & $\begin{array}{l}465.00 \\
165.83 \\
456.85\end{array}$ & $\begin{array}{r}500.00 \\
96.55 \\
489.26\end{array}$ & $\begin{array}{l}475.00 \\
133.04 \\
469.44\end{array}$ \\
\hline
\end{tabular}

Expeximenter PC (E3)

\begin{tabular}{lrrr}
\hline Content & Neutral (SI) & OR (S2) & Wrong (S3) \\
\hline $\bar{X}$ & 437.50 & 387.50 & 450.00 \\
$S D$ & 68.50 & 17.08 & 58.31 \\
$\bar{X}(a d j-)$ & 424.17 & 413.02 & 456.09
\end{tabular}


PABLI도 2

Means, Stariara Deviations, ard

Aajusted Means fol the Dart Sccres

Dart III. Neutra I. Prime (P3)

Experimenter BH (EI)

\begin{tabular}{|c|c|c|c|}
\hline Content & nüeutraI (SI) & OK (S2) & Wrong (33) \\
\hline $\begin{array}{l}\bar{x} \\
\frac{S D}{\bar{x}}(z \bar{a} j .)\end{array}$ & $\begin{array}{l}452.50 \\
179.14 \\
458.59\end{array}$ & $\begin{array}{r}537.50 \\
61.31 \\
550.07\end{array}$ & $\begin{array}{r}525.00 \\
83.47 \\
541.45\end{array}$ \\
\hline
\end{tabular}

Experimenter PG (E2)

\begin{tabular}{lrrr}
\hline Contert & Neutrai (S1) & OK (S2) & Wrong (S3) \\
\hline$\overline{\mathrm{X}}$ & 522.50 & 520.00 & 472.50 \\
$\overline{\text { SD }}(\mathrm{aqj.})$ & 26.30 & 32.66 & 97.43 \\
& 529.89 & 514.44 & 447.51 \\
\hline
\end{tabular}

Experimenter $P C$ (E3)

\begin{tabular}{|c|c|c|c|}
\hline conteint & Neutral (SI) & OK (S2) & Wrong (S3) \\
\hline $\begin{array}{l}\bar{X} \\
\frac{S D}{X}(\operatorname{ad} j .)\end{array}$ & $\begin{array}{r}472.50 \\
63.44 \\
495.43\end{array}$ & $\begin{array}{r}437.50 \\
62.38 \\
448.77\end{array}$ & $\begin{array}{r}497.50 \\
86.40 \\
468.62\end{array}$ \\
\hline
\end{tabular}


TABII

Analysis ot Covariance

summary Table for overall Aralysis

\begin{tabular}{|c|c|c|c|c|}
\hline Source & 55 & $d=$ & MS & $F$ \\
\hline \multicolumn{5}{|l|}{ Between Ss } \\
\hline $\begin{array}{l}\text { Prime (P) } \\
\text { Experimenter (E) } \\
\text { Pxe } \\
\text { Error }\end{array}$ & $\begin{array}{r}9845.63 \\
26139.50 \\
70320.25 \\
142931.06\end{array}$ & $\begin{array}{r}2 \\
2 \\
4 \\
26\end{array}$ & $\begin{array}{r}4923.31 \\
13069.75 \\
17580.06 \\
3497.35\end{array}$ & $\begin{array}{l}0.90 \\
2.38 \\
3.20+\end{array}$ \\
\hline
\end{tabular}

Within Ss

Stimulus (S)

SXF

3125.56

13496.33

$S \times E$

SXPXE

18191.88

45117.50

Error

315563.50

2
4
4
8

1562.78

$\begin{array}{lll}4 & 3374.09 & 0.57\end{array}$

0.26

$\begin{array}{lll}4 & 3374.09 & 0.57 \\ 4 & 4547.97 & 0.76\end{array}$

$8 \quad 5639.69 \quad 0.95$

\section{(1)}

(n)

5954.03

$+\quad p<.05$ 
was found between the priming groups at experimenter BF or experimenter PG. A follow-up Newman Keuls test showed the difference at experimenter $P C$ to be accounted for by a difference between the full and partial prime conditions $\{\mathrm{d} f=3.26 ; \mathrm{p}<.05\}$. Figure 1 illustrates this interaction. The partial and neutrai priming groups follow a pattern of decrease over all experinenters. The full prime group follows a similar pattern over experimenters BH and PG but is much higher than expected for experimenter PC.

\section{Test for Sequence Effect}

in aditional two-way repeated measures analysis of covariance was conducted in order to check for a sequence effest. Sequence, i.e., the oxder in which the stimuli were presented, served as the non-repeated factor with six levels. Stimulus cortent was again the repeated factor. Baselirie scores again served as the covariate. In this analysis tinere were six subjects per cell.

The two-way sequence by stimulus analysis of covariance yielded no significant main or interaction effects of the stimulus content, yielding E-values of less than 1.00 (stimulus: $E(2,59)=0.26$; stimulus $\times$ sequence: $F(10,59)=0.47$; p>.05). The main effect of sequence was also nonsignificant $(F(5,29)=2.06 ; p>.05)$.

Tests on the Model

Tests were made of the assumptions underlying both of the analyses of covariance. To test the assumption of homogeneity of variance, F-max tests were performed on the 


\section{FIGURE I}

Experimenter by Priming Condition Interaction

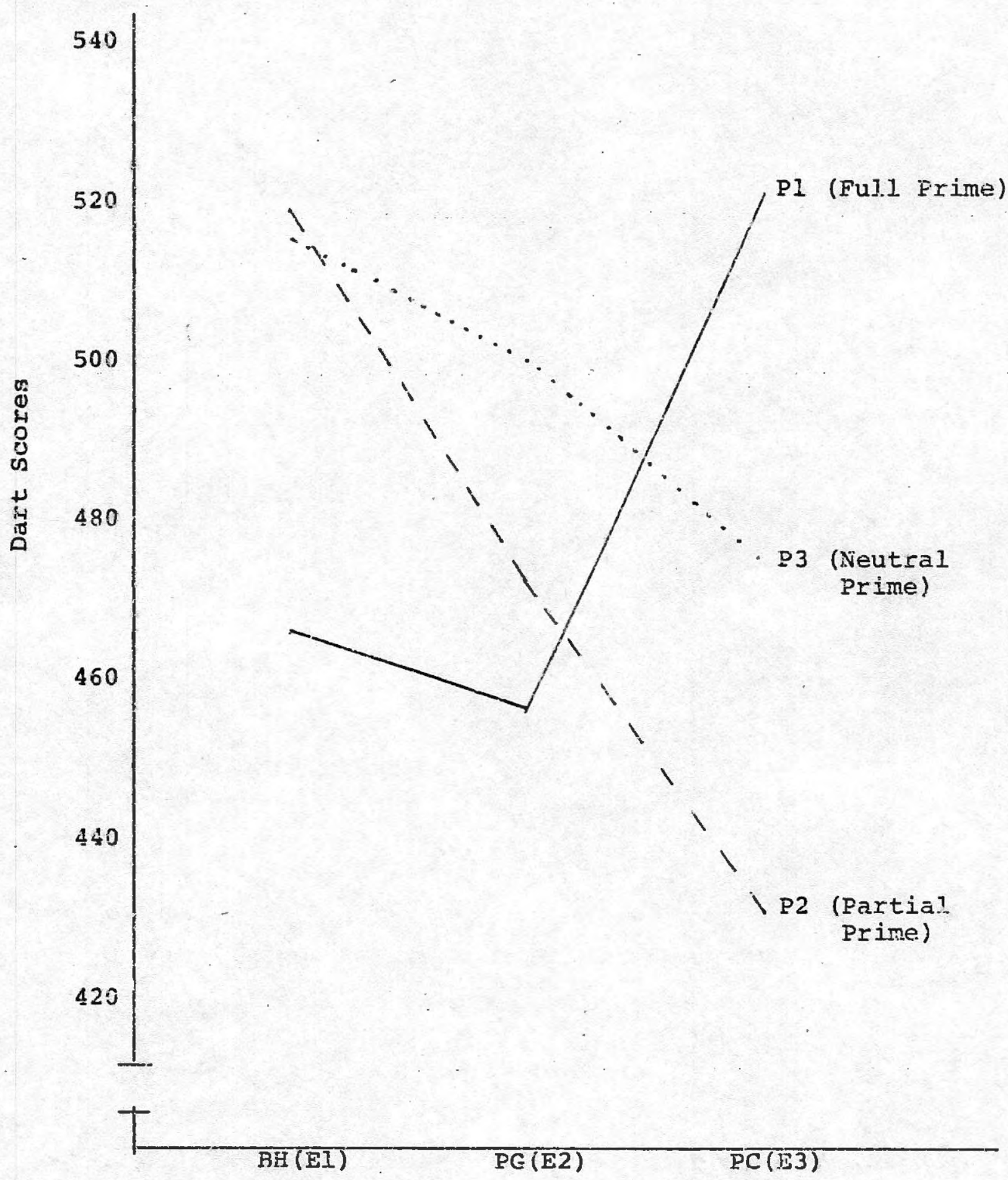




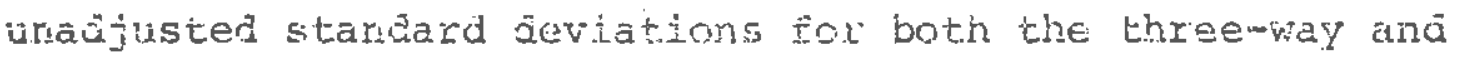
the two-way analyses of rovanance. In each case the data was cojlapsed arross leveis of stimulus, the repeated variabıe. Both F-values rere nonsignificant, (stimulus $x$ prime: $F_{\text {max }}(9,3)=13.22 ;$ p $7.05 ;$ sequence: $\underline{F}_{\max }(6,5)=4.15 ;$ $p>05)$

A three-way analysis of variance ras conducter on the baseline dart scores in order to test the assunotjon that there is no difference between the groups on the covariate. The factors were prime (three levels), experimenter (three levels) and baseline stimuius (three levels, repeated: PEOPLE ARE LOOKING, PHOFLE: ARE THINKING, ard PEOPIE ARE S'CANDING). No significant effects were found (all F's>1.00).

\section{A Priori Cormparisons}

Since otimuivs content was the most impoztant focus for replication and because of previous research findings (Silverman et al., in press), a priori comparisons of the three stimuli were conaucted for the full prine replicatior group. With all three experimenters comined, each stimulus content was compared to sach of the other two. Only the twelve subjects in the sull prime group were incluged in these comparisors. The a priori comparisons are a more sensitive test of the prejicted results than is the overall analysis of covariance. All three a priori comparisons were not significant (WRONG vs. OK: $F(1,53)=0.06$; WKONG vS. neutral: $F(1,53)=0.28$; OK vs. neutral: $F(I, 53)=0.61 ; p>05)$. As can be seen, F-levels were again less than 1.00 . 
Eecase both the overajl veac and the a priori comparisons failed to zeplicate the prericusly reported rasult:; a check was thece on the reliability of the dependent variabie. A kendelz's was conducted on the throe baseline dart scores, as these scores were neither expected to be nor found to be iniluenced by the treatment. The value of Kendell's w was .59 $\left(x^{2}(35)=61.74 ; p<.001\right)$.

Discrimination Task Analysis

The results of ali six discrimination tasks were analyzed together in a 2 by 12 Chi square. Each discrimination task was also analyzed separately in a 2 by 2 Chi Square. No significant discrimination was found in either the overal1 2 by 12 Chi square $\left(x^{2}(11)=7.64 ; p>05\right)$ or in the individual 2 by 2 Chi squares ( $A=O K, B=$ WRONG: $x^{2}(1)$ =.13; $A=$ WROliG, $B=O K: x^{2}(1)=.13 ; A=O K, B=$ neutral: $x^{2}(1)$ -.31; $A=$ neutra1, $B=O K: x^{2}(1)=.03 ; A=W R O N G, B=$ neutral: $x^{2}(1)=2.56 ; A=$ neutral, $\left.B=W R O N G: x^{2}(1)=1.40 ; p>0.05\right)$. 


\section{DISCUSSION}

The mot strikjng finding of this study was its failu:e to replicate the results of silvernan et al. (in press). Improvenent of dart throwing performance after viewing the stimuius BEATING DAD IS OK and worsening of performance after seejing BEAIING DAD IS WRONG were not found to occur. This was true not only of subjects in the partial and neutral priming groups, who were treated somewhat differently from sijverman's subjects, but also of subjects in the Full prime replication group. Even a priori comparisons conducted on the full prime growp failed to yield the significant differences precicted. The lack of replication occurred in spite of the design outlined by silverman being closely followed, including clarification of procedures through personal communications.

The lack of replication indicates that if there is an effect of subliminal oedipal stimulation on dart throwing performance, it is at best a weak one. Specifically, the failure to replicate throws some doubt onto the reliability and/or generalizability of the findings of Silverman and his associates. As the results of the discrimination task of the present study show the stimuli to be adequately subliminal, a difference in the subliminality of the stimuli is unlikely to be yielding the differential results. Rather, the first 
explanation that rust be considered is that sijverman's results were due to Iyps j. error. one contributor to that error couid be the inadequate rejiability of dart throwing as a dependent variable. A coefizient of agreement of .59 between the three baseline scores indicates that at lesst some of the charge on the dependert variable mizy be caused by the insufficient reliability of dart throwing as a dependent measure.

However, while this stcöy failea to replicate, two other attempts at 1eplication, which have become available since this study began, were more successful. Lonski and Falumbo (Note 5), using urdergraduates at fonstra briversity as subjects, did a dart throwing study using the stimuli BEATINE DAD IS OK, BEATIITG DAD IS WRONG, PEOPIE ARE WALKING, BEATING MOM IS CK, and BEATING MOM IS WRONG. Their one significant finding was a difference between the two BEATING DAD stimuli $(p<.05)$. However, their overall anaiysis of covariance did not yieid any significant results. It was only when a separate analysis of covariance was carried out between the two BEAIING DAD stimuli that the expected significant result was found. This indicates an effect less strong than that found by Silverman and his associates. Lorski and Palumbo also ran the study on female undergraduates (stili using male experimenters) and found no significant differences. It should be noted that their one significant finding was out of 20 possible comparisons. Lonski and Palumbo do not state how many of these possible comparisors they conỏucted. 
The other replicatioı dickmt was carrieã out on male undergraduates at Brown jinlvs:sitz (Silvsrstein, Note 6). Silverstein conducted trree separate studies, the first of which was a replication of the two BEATING DAD stimuli, plus MOMMY AND I ARE ONE and PEOPIIE ARE WXEKING. A.lthough Silverstein found the two BEATING DAD stimuli to differ significartly $(\underline{p}<.05)$, his results must be viewed with caution because of his method of data analysis. Rathex than perform an analysis of covariance, silverstein did a series of t-tests on the baselins-critical difference scores, a procedure far more likely to result in Type I error. In addition, he dia not replicate in his second study, in which the two BEATING DAD stimuli plus the messages DEFEATING DAD IS OK and DEFEATING DAD IS WRONG were used. Instead, in the second study the one significant t-test $(p<.05)$ was a comparison of EEATING DAD IS WRONG With DEFEATING DAD IS OK. Siiverstein's third study was designea to test the opposite side of the pedipal conflict with the following stimuli: WINNING MOM IS OK, WINNING MOM IS WRONG, WINNING DAD IS OK, and WINNING DAD IS WRONG. The two WINNING MOM stimuli were found to differ significantly $(p<.05)$ in the predicted direction. It should be noted that a t-test on the two most divergent mean aifference scores yielded the only sigrificant results in each study.

Although these other investigators have replicated Silverman and his associates' rindings, they have found a considerably weaker effect than silverman reports. In addition, no effect at all was found in the present study. 
The question, then, is one of wrying to account for the discrepant results of afferent jabusatories. One possihle explanation is that Silverman's findings have Iimited generalizability. More specificaily, the discrepancies in the results may be aue to differences in the zubject populations at the various research settings.

One difference that is imanediateiy striking is that Brown, HoIstra, and New York Universjty are all private universities whereas the University of Rhode Island is not. Three possible differences among students at private and public univecsities may be important. First, given the prestige of attending a private college and the competition of admission to sne, students there nay be more ambitious, achievement criented, and competitive than are students at a state school. Second, parents who woula pay the hich costs of private education, whatever their socioeconomic level, may be moxe ambitious for their children than parents of similar socioeconomic status whose chilären attend a public universicy. One explanation of the different results, then, is that more ambitious stuajents or students more pushed by their parents evidence oedipal dynamics more often or more easily than their less ambitious counterparts. Of course, before this explanation can be more than conjecture, Iurther research is necessary comparing groups preselected For the amount of competitiveness or achievement orientation. Such a comparison was attempted by Silverman and his associates in their third dart study, but because this study yielded ro significant results at all, the question remains 
unanswered. No further attompts at exploration along these lines have been reported. The results of the present study indicate that such would be a usefur path to pursue.

The third possible difference in populations at public and private universities is one of socioeconomic status itself; that is, students at a private university probably come from families of a higher socioeconomic level. Two speculations can be offered about this difference. First, there may be more competition and achievement orientation within the upper nicale class subcuiture and therefore a greater prevalence of oedipal conflicts within this group. But it is also true that Freud and many later psychoanalysts came from the upper middle class. More importantly, most of their patients were middle class as well. and it was from the analyses of these patients that the theory developed. Therefore, one reasonable speculation j.s that oedipal conflicts are more likely among upper middle class subjects simply because it is primarily to upper midale class people that the theory applies.

Similarly, anothes rather intriguing speculation arises from the association of psychoanalytic theory with another particular group. In addition to being upper middle class, Sigmund Freud and many later psychoanalysts were also Jewish. Several theorists have hypothesized a relationship between Freud's ethnicity and his theory (c.g., Grollman, 1965). It is of note, then, that a second major population difference among the schools in question is a difference in the proportion of Jews in their student 
bodies. Information gatherad fros: the Jewish student organizations or the four schools reveal that the three where the dart study yielded significant effects have a higher percentage of Jewish students than does the Universj.ty of Rhode Islana. Specifically, both Hofstra (Notej 7) and Brown (Note 8) report estinates of Jewish students three times as great as the estimate of $10 \%$ reported by the University of Rhode Island (Note 9). In addition, a report from the Jewish Association of College Youth (Note 10) indicates that New York University, where the strongest efrects of the dart throwing paradigm were found, has one of the largest percentages of Jewish students of any college in the United States. It could be, then, that psychoanalytic postulates, and specifically in this case oedipal conflicts, are more uniquely ethnic phenomena than is commonly supposed. Again, it must be cautioned that the only way this iypothesis could be verified is by comparing at similar universities Jewish and non-Jewish students close in age, socioeconomic status, and other relevant variables.

In spite of the lack of replication in the present study, one significant result was yielded by the analysis of covariance; this was an interaction between prime and experimenter. As there is a $30 \%$ chance of finding one sig-

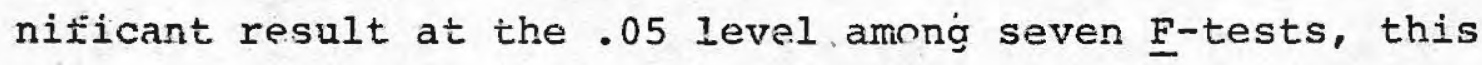
finding could be due to chance. Such a conclusion must especially be considered since the significant effect was unexpected ano is difficult to understand.

There are other possible meanings of the interaction, 
however, which should be englored. It will be renembered (see Figure I) that the most different group is the fuli prime replication group tested by Experimenter FC. It will also be remembered that PC is the only clinician of the three experimenters and the only one fully trained in the administration of projective tests, which were used as part of the priming material for this group. It could be, then, that FC's administration of the projectives was different. from that of the cther experimenters and that he therefore in some way enhanced subjects' dart throwing ability. This hypothesis is made less tenable, nowever, by the fact that projectives were also administered in the partial prime condition where PC's subjects did worst.

As it will also be remembered that PC is the only psychoanalytic proponent among the experimenters, it might be hypothesized that there was an experimenter expectancy effect. Specifically, perhaps because PC wished for the replication to succeed, he subtiy encouraged subjects in the replication group to do well. Given the failure of the replication, it could also be hypothesized that because PC was blind as to stimulus content he could not influence subjects' differential performance but only their performance under all conditions.

In the other dart studies, however, perhaps even the differential performance of subjects according to stimulus content was ireluenced by experimenter variables. This could occur if some experimenters are able to arouse oedipal confilcts more easily than others: Though silverman et ai. 
(in press) found the age of the experimenter not to have this effect, it is possible that nore subtle experimenter characteristics do. One such characteristic could be the experimenter"s own oedipal conflicts. Specifically, as researchers tend to study phenomena they are personally interested in, it is not unreasonable to assume that most experimenters in these studies have been proponents of psychoanalytic theory. Going further, it could be speculated that their interest in studying oedipal conflicts arises because they find its tenets personally applicable. One could further speculate, then, that perhaps it takes a person himself so conflicted to arouse the conflict in someone else, possibly by being nonverbally less supportive of subjects' failures. Whether or not this is the case, the fact that the present study revealed experimenter differences should caution future investigators to examine closely experimenter variables in their work. Another direction for future research would be to examine experimenter effects more systematically, perhaps by comparing experimenters preselected on the basis of theoretical bias, achievement orientation, or oedipal competitive conflicts.

At a minimum, the results of the present study seem to iend support to the growing body of literature since Malinowski (1924) that raises serious doubts about the universality and centrality of the oedipal complex for all individuals. The resuits of our study, taken together with the results of other dart stuaies, suggest that if. there is any impact at all of unconscious oedipal strivings, such 
impact is probably Iimitec by thr pelsorality and/or cultural characteristica or suojects and/or experimenters. 
1. Silverman, L. E. Ethical considerations and guidelines in the use of subliminal psychodynamic activation. Unpublished manuscript, 1977. (Availab]e from Research Center for Mental Health, New York University, 6 Washington Place, New York, New York 10003).

2. Silverman, L. H., Martin, A., Ungaro, R., \& Mendeisohr, B. The effect of subliminal stimulation of symbiotic fantasies on behavior modification treatment of obesity. Manuscript submitted for publication, 1977.

3. Silverman, I. H., CandeII, P. Pettit, T. F., \& Elum, E. A. Further data on effects of aggressive activation and symbiotic merging on the ego functioning of schizophrenics (extended report). Unpublished manuscript, 1971. (Available from Research Center for Mental Health, New York University, 6 Washington Place, New York, New York 1.0003).

4. Silverman, I. H. Personal communication, November 1977.

5. ionski, M. \& Palumbo, R. The effects of sublimirial stimuli on competitive dart throwing performance. Manuscript submitted for publication, 1978.

6. Silverstein, R. The effects of tachistiscopic cedipal stimulation on competitive dart throwing. Unpublished manuscript, 1978. (Available from Psychology Department, Brown University, Providence, Rhode Island 02906).

7. Fischer, F. A. Personal communication, August 1, 1978 .

8. Kronish, M. Personal communication, June 1978.

9. Rarnofsky, K. Personal communication, June 28, 1978.

10. Bloom, M. Personal communication, June 27, 1978. 
Ance12, M. J. The effect of priming and the subliminal presentation of sexual and aggressive stimuli on tests of creativity (Doctoral dissertation, New York Universicy, 1969). Dissertation Abstracts Interna-

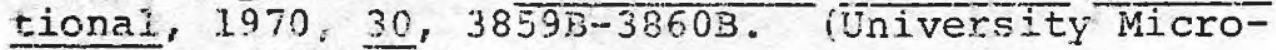
films No. $70-3 \overline{03} 3$ )

Beisser, A. R. Psychodyranic observations of a sport. Psychoanalytic Review, 1961, 48, 69-76.

Bronstein, A. A. An experimental study of internalization fantasies in schizophrenic men (Doctoral dissertation, Yeshiva University, 1976). Dissertation Abstracts International, $1977,37,4665 \mathrm{~B}$. Tuniversity Microfilms No. 77-5001)

Campbell, D. P. Strong Vocational Interest Blank: Manual For the strong-Campibell Interest Inventory. Stanford, CaIif.: Stanford University Press, 1974.

Cox, I. D. Depressive symptoms as affected by aggressive stimuli subliminally and supraliminally presented (Doctoral dissertation, Fordham University, 1974). Dissertation Abstracts International, 1974, 35, 1402B-1403B. (University Microfjlms No. 74- $\overline{20}, 332$ )

Eagle, M. The effects of sublininal stimuli of aggressive content upon conscious cognition. Journal of Personality, 1959, 27, 578-600.

Ellman, C. S. An experimental study of the female castration complex (Doctoral dissertation, New York University, 1970). Dissertation Abstracts International, 1971, 31, 4987 B-4988B. (University Microfiims No. 71-2282)

Encyclopedia Americana (VoI. 3) . New York: Americana Corporation, 1965 .

Exner, J. E.: Ir. The Rorschach: A Comprehensive System. New York: John wiley \& Sons, 1974.

Gadlin, W., \& Fiss, H. Odor as a facijitator of the effects of sublimiral stimulation. Journal of Personality and Social Psychology, 1967, i, 95-100. 
Golland, J. H. The effacts -f oporimental dive arousal on respoise to subliminal stimulation (Doctora]. dissertation, New York University, 1966). Dissertation Abstracts, $1967,27,4233$. (University MicroFilms No. $6 \bar{i}-202 j$.

Gordon, C. M., \& Spence, D. P. The racilitating effects of food set anä food ceprivation on responses tc a subliminal food. stimuliss. Journal of Personality, 1966 , 34. $406-415$.

Grollinan, E. A. Judaism in Sigmund Freud's World. New York: Appleton-century, $\overline{19} 6 \overline{5 .}$

Guthife, G., \& Wiener, M. Sublininal perception or perception of partial cues with pictorial stimuli. Journal of Personality and Social Psychology, 1956, 3 , fil $9=62 \bar{\gamma}$.

Kaplan, K. B. The symbiotic fantasy as a therapeutic agent: An experimental comparison of the effects of three symbiotic elements on manifest pathologi in schizophrenics (Doctoral dissertation, New York Univecsity, 1976). Dissertation Abstracts International, 1976. 37. $1437 \mathrm{~B}-1438 \mathrm{~B}$. (University Microfilms Ho. 76-19, 51.2)

Kaye, M. M. The therapeutic value of three nerging stimuli for male schizophrenics (Doctoral dissertation, Yeshiva University, 1975). Dissertation Abstracts International, $1975,36,143 \overline{8 B-14398 . ~(I n i v e r s i t y ~}$ Microfilms No. $75-20,571$ )

Klein, G. S. Psychoanalytic Theory: In Exploration of Essentials. New York: Internaticnal Universities Press, 1976.

Lasser, E. S. Ethical considerations in pathology-intensifying research. American Psychologist, 1077, 32. $577-578$.

Lomangino, L. F. Depiction of subliminally and supralininally presented aggressive stimuli and its effects on the cognitive functioning of schizophrenics (Doctoral dissertation, Fordham University, 1969). Dissertation Abstracts International, 1969, 30, 1900B-1901B. (University Microfilms No. 69-16, 226)

Malino:vski: B. Psycho-analysis and anthropology. Psyche, 1924 , 4 , 293-332.

Miller, J. The effects of aggressive stimulation upon young adults who have experienced the death of a parent during childhood and adolescence (Doctoral dissertation, New York University, 1973). Dissertation Abstracts Internationa1, 1974, 35, $\frac{1055 \mathrm{~B}-10563 \text {. }}{105}$ (University Microfilms No. $74-1 \overline{6}, 847$ ) 
Moliarty, J. ․ Cognitive functioning of schizophrenics as affected by aggressure stimuli subliminally and supraininally prasented (uncioral dissertation, Fordham University, 1968). Djssertation Abstracts, 1968, 29, 775B. Oriversity Microfilms No. 68-11, 021)

Rustein, E. H., \& Goldberger, I. The effects of aggressive stimiation on suicidai patients: An experimentel study of the psychoanalytic theory of suicide. In 3. Rubinsicein (Ea.), Dsychoanalysis and Contemforary Science (Vol. 2). New York: Macmilian, 1973.

Schafer, R. A New Language for Psychoanalysis. New Haven, Conn.: Yale university Press, 1976.

Silverman, L. H. A study of the effects of subliminally presented aggressive stimuli on the production of pathological thinking in a nonpsychiatric population. Journal of Nervous and Mental Disease, 1965, 14i, $443-455$.

Silvermar, I. H. A techilique for the study of psychodynamic relationships: The effects of subliminaliy presented aggressive stimuli on the production of pathological thinking in a schizophrenic population. Journal of Consulting Psychology, 1966, 30, 103-111.

Silvermen, I. H. Further comments on matters relevant to investigations of subliminal phencmena: A reply. Perceptual and Motor Skilis, 1968, 27, 1343-1350.

Silverman, L. H. An experinental technique for the study of unconscious conilict. British Journal of Medjcal. Psychology, 197.1, 44, 17-25.

Silverman, I. H. Psychoanalytic theory: "The reports of my death are greatly exaggerated." American Psychologist, $1976,31,621-637$.

Silverman, L. H. Two unconscious fantasies as mediators of successful psychotherapy. International Journal of Psychoanalytic Psychotherapy, in press.

Silverman, L. H., Bronstein, A., \& Mendelsohn, E. The further use of the subliminal psychodynamic activation method for the experimental study of the clinical theory of psychoanalysis: On the specificity of the relationship between symptoms and unconscious conFlicts. Psychotherapy: Theory, Research, and Practice, $1976,13,2-16$.

Silveman, L. H., \& Candel1, P. On the relationship between aggressive activation, symbiotic merging, intactness of boay boundaries and manifest pathology in 
schizophranics, Aouthai tof Fervous ard Mental Disease, 1970, 150, $317-3$ s.

Silverman, I. F., Candell, P. Pettit, T. F., \& Blum, F. A. Furthez atata on the efects of aggressive activation and symbiotic nerging on the eqo functioning of schizophrenics. Eerceptual and Motor Skills, 1971, $32,93-94$.

Silverman, I. H., Frank, S. G., \& Dachinger, F. A psychoanalytic reinterpretation of tire effectiveness of systematic desensitiation: Experimental data bearing on the role of merging fantasies. Journal of fibnormal Psychology, $1974,83,313-318$.

Silverman, I. H., \& Goldweber, A. M. A turther study cf the erfects of subliminal. aggressive stimulation or thinking. Journal of Nervous and vientai Disease. $1966,143, \overline{463-472}$.

Silverman, I. H., Klinger, F., Lustbader, M., Farre1I, J., \& Martin, A. D. The effects of subliminal drive stimilation on the speech of stutterers. Journal of Neryous and vent.al Djesease, $1972,15.3,44.2 \mathrm{~T}$.

Silverman, I. Fi., Kwawer, J. S., Wolitzky, C., \& Coron, M. in experimental siudy of aspects of the psychoanalytic theory of maje homosexuality. Journal of Ainormal Psychology, 1973, 82, 178-138.

Silverman, I. H., Levinson, R., Mendelsohn, E., Ungaro, R., \& Bronstein, A. A. A clinjcal appitcaticn ö subliminal psychodynamic activation. Journal of Nervous and Mental Disease, 1975, 161, 379-391.

Silverman, L. H., Pettit, T. F., \& Dunne, E. J. On the relam tionship betweer self-object differentiation, syimbiotic experiences and pathology reduction in schizophrenia. Journal of Nervous and Mental Disease, $1971,152,118-1 \overline{28}$.

Silverman, L. H., Ross, D. L., Adler, M. M., \& Iustig, D. A. A simple research paradigm for demonstrating subIiminal psychodynamic activation: The effects of oedipal-related stimuli on dart throwing accuracy in college males. Journal of Abnormal Psychology, in press.

Silverman, L. H., \& Silverman, D. K. A clinical-experimental approach to the study of subliminal stimulation: The effecis of a drive related stimulus upon Rorschach responses. Journal of Abnormal and Sociaz Psychology, $1964,69,1.5 \overline{8-172 .}$ 


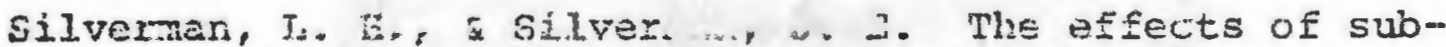
liminaliy presented d*tve stimuli on the cognitive functioning of schizophrenics. Journal of Frojective Technigues, 1567, 78-85.

Silverman, 5. F.y Exiro, R. H. Further investigations of the effects of subliminal aggressive stimulation on the ego furctioning of schizophrenics. journal. of Consultirg Psychology, 1967, 31, 225-232. (a)

Silverman, L. H." \& spiro, R. H. Some comments and data on the partial cue controversy anc othor matters relevant to investigations of subliminal vhenomena. Perceptua! and Motor. Skills, 1967, 25, 325-333. (b)

Silvermin, I. H., \& Spiro, R. H. The effects of subliminal, supraliminal and vocalized aggression on the ego functioning of schizophrenics. Journal of Nervous and Mental. Disease, 1968, 146, 50-61.

Silverman, L. H., Spiro, R. H., Weisberg, J. S., \& Candell, P. The effects of aggressive activation and the need to merge on pathological thinking in schizophrenia. Joirnal of Nervous and Mental Disease, 1969, 148, 39-51.

Silverstein, A. Acquired word value, verbal learning and retention: Replication and extension. Psychological Reports, 1966, 18, 357-358.

Spence, D. P., \& Ehrenberg, B. Effects of oral deprivation on responses to subiiminal ana supraliminal verłal food stimuli. Journal of Abrormal ani Social Esychology, 1964, 69, 10-18.

Spence, D. F., \& Holland, B. The restricting effect of awareness: A paradox and an explanation. Journal of Abnormal and Social Psychology, 1962, 64, $1 \overline{63-174 .}$

Spiro, R. H., \& Silvenian, L. H. Effects of body awareness and agglessive activation on ego functioning of schizophrenics. Derceptual and Motor Skills, 1969, 28. $5: 75-585$.

Weiner, M.; \& Kleepsies, P. Some comments on partial cue controversy and other matters relevant to investigations of stbliminal phenomena: $f_{2}$ rejoinajer. Peresptuai and Motor skills, 1968, 27, 842-861.

Varga, M. P. An experimentai study of aspects of the psychoanalytic theory of elation (Doctoral dissertation, NerN York University, 1973). Dissertation Abstracts

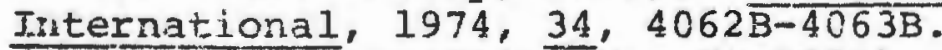

(University Microfims No. 74-1981) 
AEPEN N

59

SUBLIMINAI, SMTMULI.

Critical stinaius I

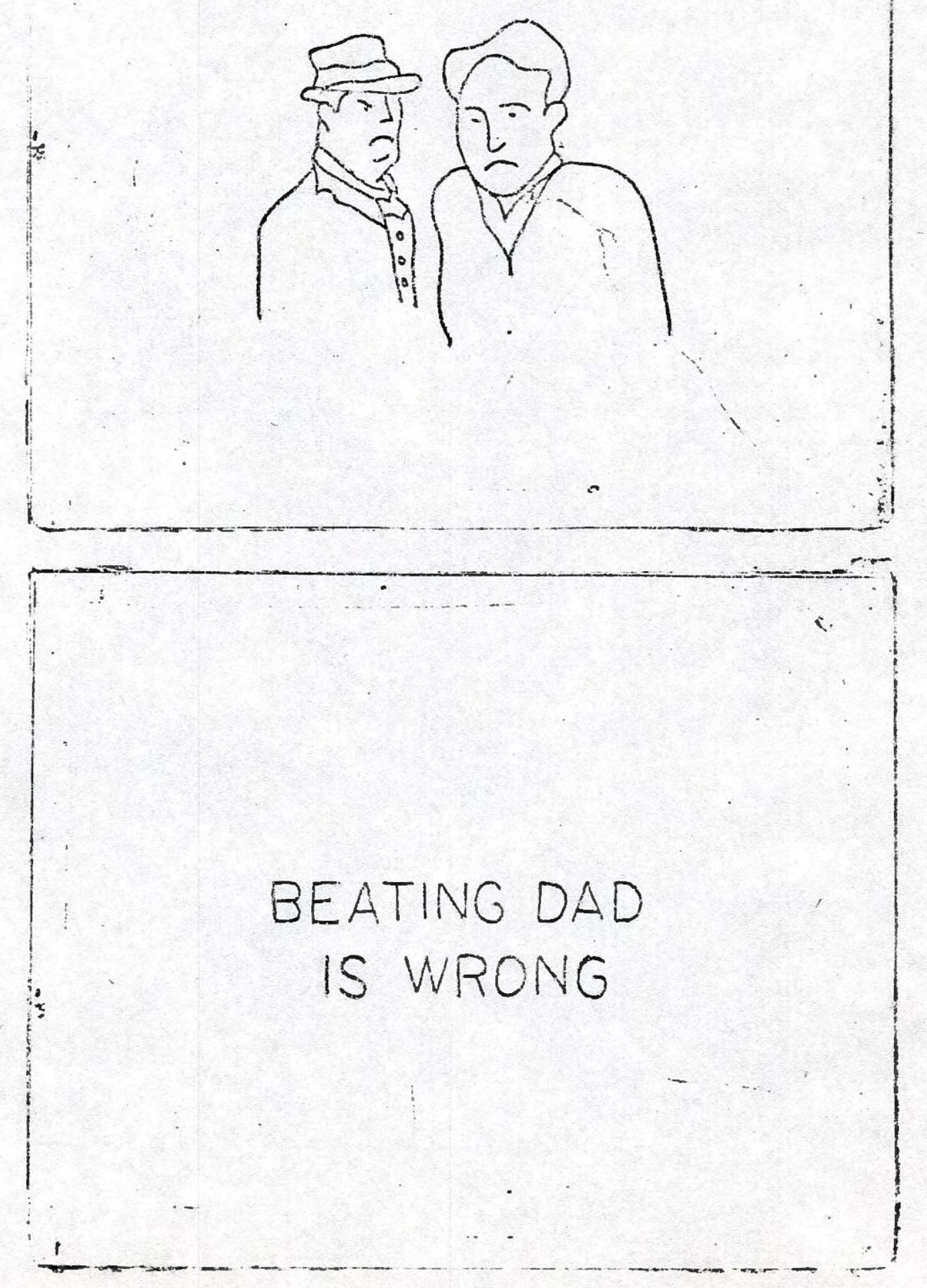


Critical stimuius 2
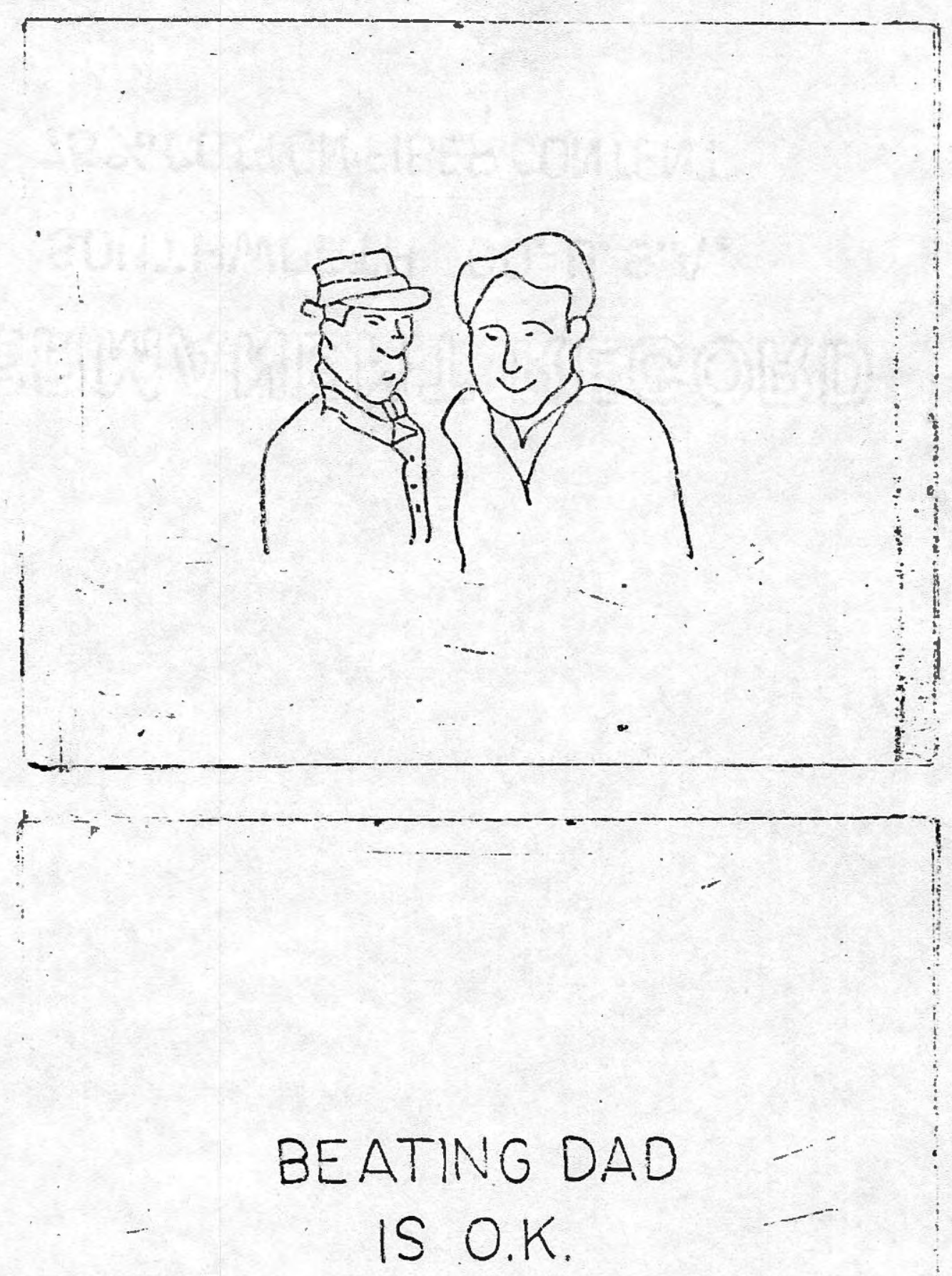

!

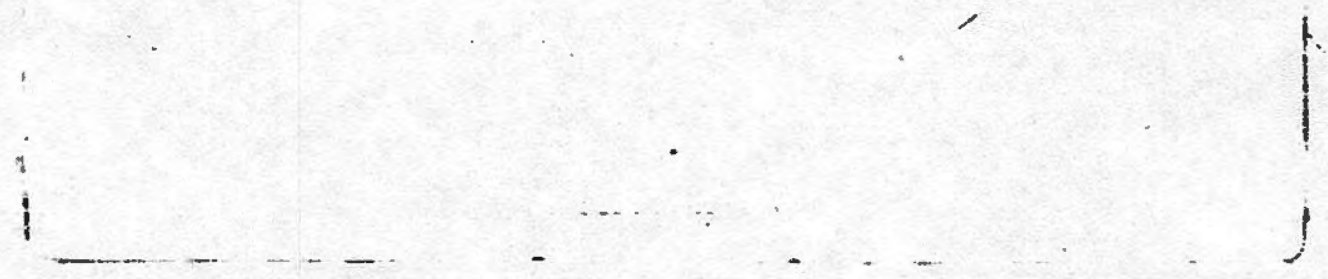


Critical stimulus 3

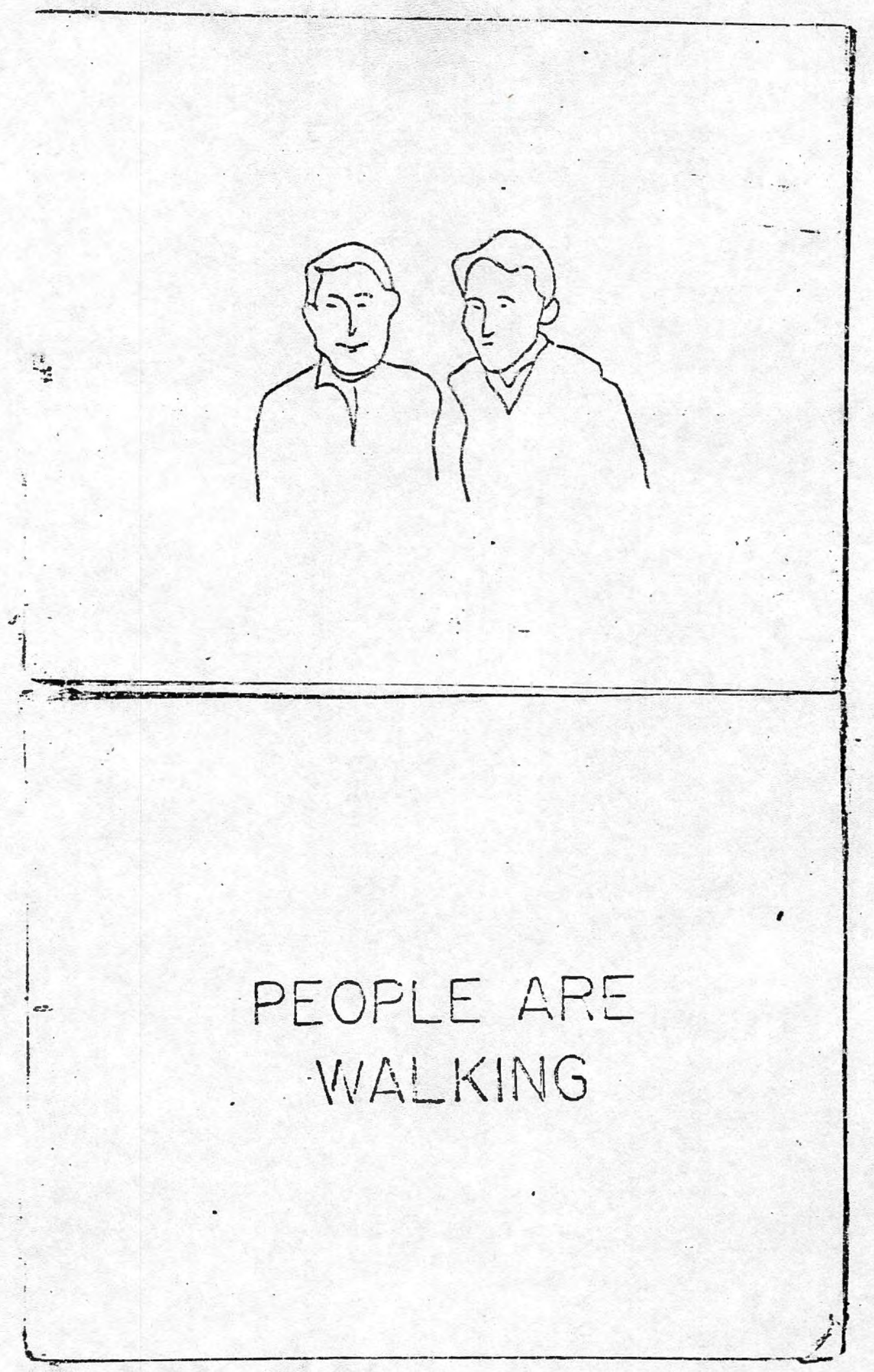


Baseline Stimulus =

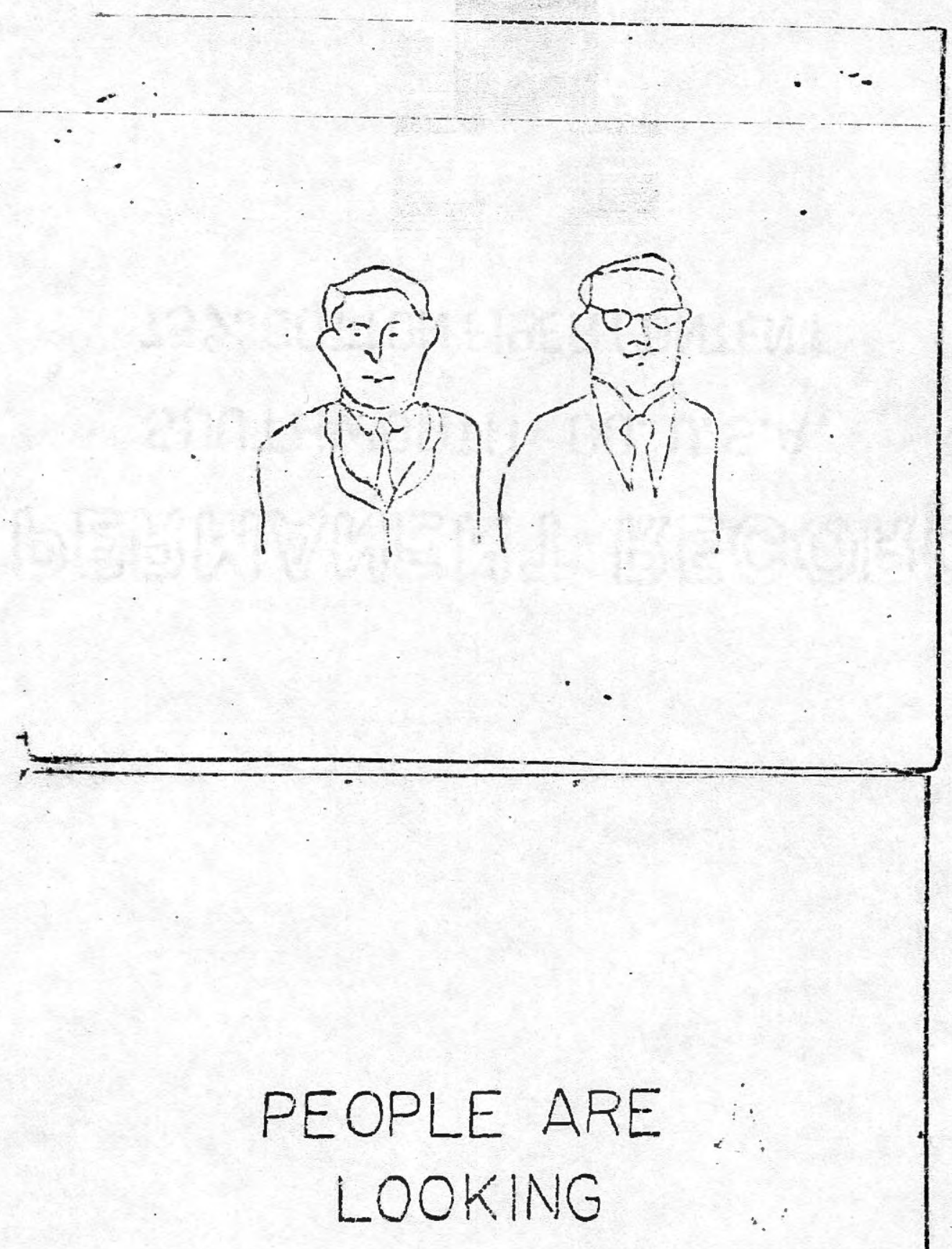


Baseline Stimulus 2

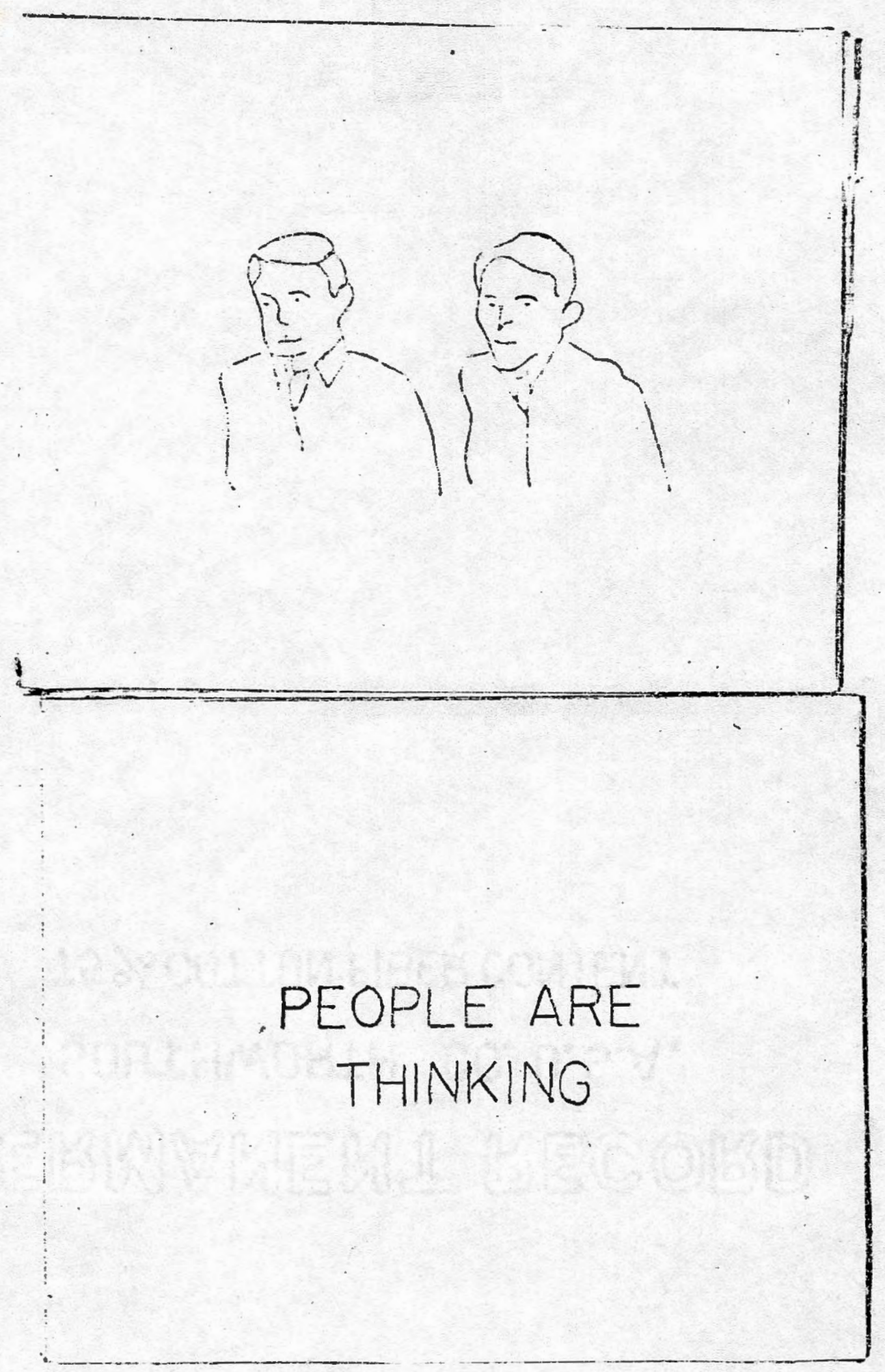


Baseljule Stimizils 3
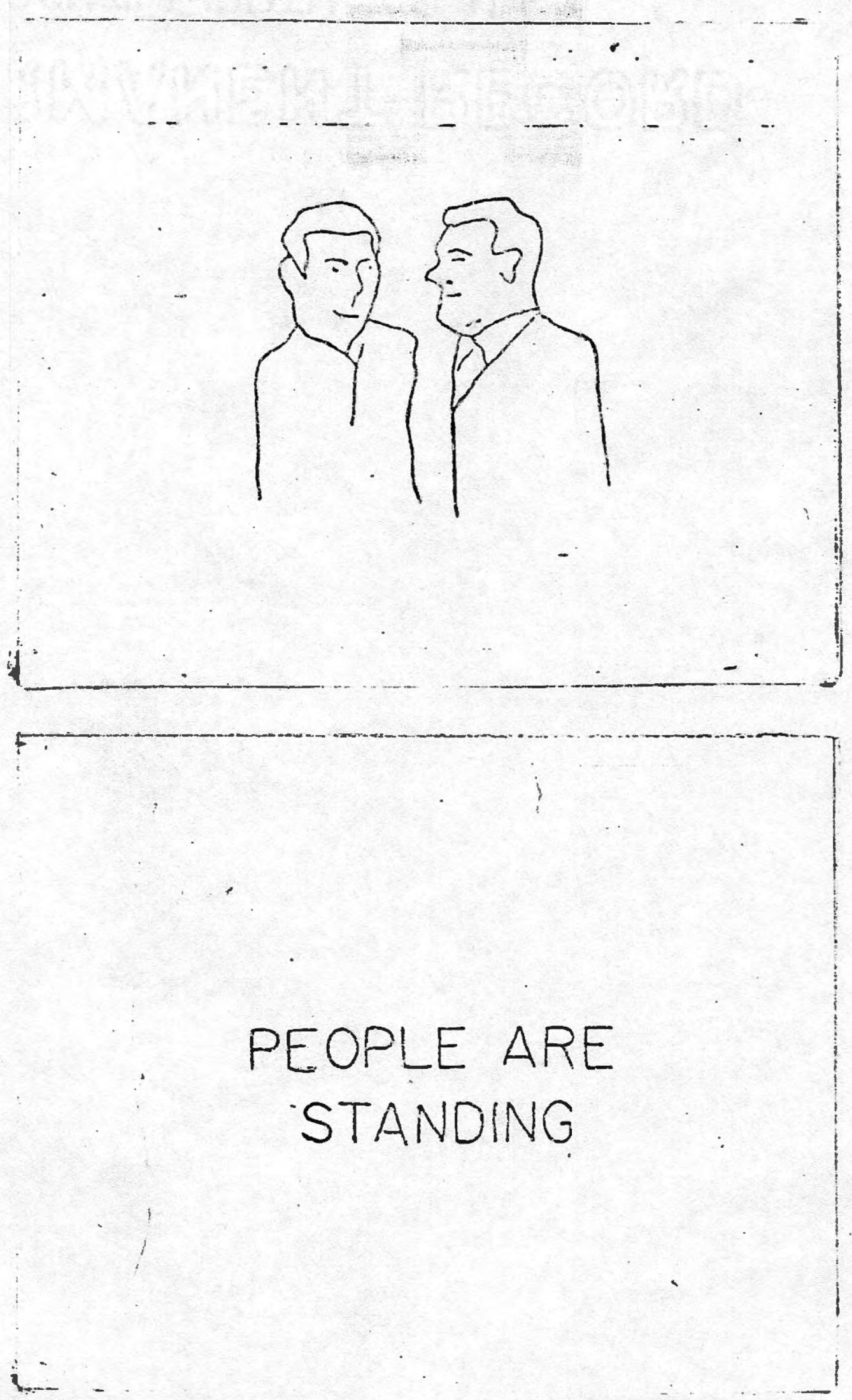
APPENUIX $B$

OEDIPAL QUESTIONNAIRE

Name

Age

Aāaress

Phone \#

Level of Education G.P.A. Narried? Parent?

Father's occupation Your Gccupaticnal Goal

By circling the appropriate letter please indicate to what extent you agre or disagree with the statements below.
a) strongly agree
b) agree
c) disagree
d) strongly disagree

A. I am a competitive person.

a b c a

B. I would rather be "alone, at the top" than part of the masses.

a $\quad b \quad c \quad d$

C. I have a relatively conflict-free relationship with my mother.

a $\quad b \quad c \quad d$

D. I am close with my mother.

a $\quad b \quad c \quad d$

E. I have a relatively conflict-free relationship with my father.
a $\quad b \quad c \quad d$

F. I am close with my father.

a $\quad b \quad c \quad d$

G. It is difficult for me to be assertive with other peopie. a $b \quad c \quad d$

H. I am prone to feel guilty about things more than most people.

$$
\text { a } \quad b \quad c \quad d
$$

I. Most people woula consider my father a success.

$$
\text { a } b \quad c \quad d
$$

J. I consider my father a success.

a b c d 
APFFITLIK C

OEDTPAL STORY FOR GTORY RECALI

Ithis is 2 mother and her son standing there in a state of stunned silenze. Just moments before, the father was also there, but he has stomed out of the room feeling extremely anciy towards lis son. They had had a loud argument in which the son told his father that he was no longer competent to run the family business, that he shoula reiire, and that he (the son) should take over. Since the mother plays an important roie in the runuing of the business, this world give the son an cpportunity to fulfill a long-harbored secret wish of. his: to spend more tire fith fier and enjoy more often the closeness they"ve shared. in the past. In his anger at being criticized by his son, the father threatened to ostracize the son altogether from the family business. As he stormed out. of the room he cautioned: "Just remember who"s still the father around here." "The son is now feeling guilty and fears that he may have overstepped his bounds. Fe is also afraid that he has chreatened the closeness which he and his father often experience together. The mother is torn between her love for her husband and her love for her son. 
AFPEVIIX

NEUTRAT, QUESTRONENATRE

Name Ige

Adaress Phone \#

Years in School Iive ort Càmons? Married? Farent? Major Home rown

By circling the appropriate letter please indicate to what extent you agree or disagree with the statements below.
a) sironaly agree
b) agree
c) disaçree
d) strongly disagree

A. I enjoy camoing.
a b $c$ a

B. I like looking at things in a clothing store. a b c d

c. I prefer reacing a book to watching tr or going to a movj.e.
a $\quad b \quad c \quad a$

D. I like people who daydream a lot.
a b c d

F. I. Iike looking at things in a hardware store. a b c d

F. I. like conventions.

$$
\text { a b c d }
$$

G. I enjoy raising flowers and vegetables.
$a$ i $c$ d

H. I like inving in the city.
a $\quad b \quad c \quad d$

I. I prefer outside work to insiāe work.
a $b \quad c \quad d$

I. I like tinkering with small hand tools.

$$
a b \quad c \quad d
$$


APPNDIX $\Xi$

NEUTRAJ, STORY FOR STORY RECALI

Belgium is a smal.1 country not much larger than the stats of Maryland. It is one of the most densely populated nations in Europe. It lies at the crossroads of the continent and is a stopping place for travelers or their way to London, Paris and other world capitals. Because of its location, it is the scene of mary international conferences and the headquarters of international government and business orgarizations. As a whole. Belgiun's physical aspect presents no extremes. The lines of its horizon are calm, the slopes of its hilis are soft, and the depressions soread out gently. The climate, which is rainy and damp in the greater part of the country calls for protection: raincoats and umbrellas are a component part of everybody's outfit. Although it must be considered a hazardous enterprise to define the national characteristics of a country, it is Generaily agreed in the case of Belgium that the inhabitants are essentially reasonable, sound, reliable, not given to any excess with regard to their way of living and thinking. They are very fond of music and the theater, and even smallsized towns find it impossible to do without en opera company. 


\section{APPENDIX \\ DETAIJS OE PXFERTMENTER-SUBJECT INTERACTION} Before S arrives: Turn on scope, adjust lights, arrange

When S arrives: "I'm and as you know this is a study of factors that influence competicive performance. We can begin by your reading this information sheet. " Show S sheet (see Appendix G), have him sign consent form (see Appendix $\mathrm{H}$ ), then say "In addition to vinat was described on there, I want to add that the tournament pari of the axperi* ment will involve your throwing darts at the dari board up there. Before we get to that, however, let me expiain about this equipment."

Peassurance about Tach: "The equipment here is called 2 tacinistoscope, and will be ased in the experiment. it can regulate precisely the amount of time a picture or message can be flashed and seen. In this experiment we wiil be İashing messages or pictirss at a speed of 4 ore-thousands of a second, a speed at which you would probably be aware only of a brief flash or flicker of light. The messages or pictures should register in your mind, however, and after the experiment you will have an opportunity to find out about the content of the stimuli you were shown."

Questionnaire: "Now I would like you to fill out this

Rorschach Card: "Now I am going to show you an ink blot, and I want you to tell me what you see. There are no right or wrong answerg, different people see difierent kinas of things. If you should see more than one thing in the card, then tell me everything it looks like to you." Do inquiry as to location only. Do not allow ss to give more than 8 responses.

TAT Card 7BI or photograph \#1: "Now I am going to show you a picture, ard i would like you to nake up a story about the picture, haring a past, present, and a future or outcome." Inquire into outcome if not spontaneously given. Inquire if an emoticnal description is used that is unclear.

TA' Card 6BM or photograpt $\# 2$ : ditto

Story Recall: "Now I an going to read you a story we made ip 
for the purpose of this experinent about this picture, and I will ask you to recall it back to me after I firish reading it." Read story. "I woul? like you "o recall the story as best you can, and teli it back to me."

Exclanation of Tournament: "Okay, now we come to the tournament. Is you can see, the top places so far are iisted over here (see rocm diagram, Appendix L). The top three places in the tournament will receive cash prizes of $\$ 12$, $\$ 8$, and $\$ 5$. I'm goirg to have you throw a total of 48 darts. You will throw 6 series of 8 darts, and before each series you wi.ll. sit over here and look into the tach. vour grand score will count in the tournament. Before I give you the instructions about that, why don't you come over and throw 8 practice darts? Stand behind this line, throw 4 darts, go and get them out yourself, and theil throw 4 nore. Make sure you throw them hard enough so they sicick. If a dart doesn't stick, or if it falls out, your score for that throw will be zero."

Touriament Procedure: "Now, if you will come with me. You will sit here and look into the tach. I will be at the controls over here, and I. will say 'Ready, set' and then press a button which will produce a flicker of light. obviously, it's these flickers of light that contain words and pictures that are meant to affect your competitive perfomance. I can't tell. you now what these words and pictures are, but you will be told later on. After seeing several fiashes you will get up and throw a series of 8 darts. Then you will come back and look into the tach again. If you have any guestions, hold them until the end of the experiment, and we can discuss them then. Now, look into the tach. Do you see a dot? okay, try to focus on that. During the time we are doing this part of the experiment, try not to blink, and don't look up from the machine. I will show you a flash, wait a few seconds, then show you another. You will see 8 flickers in all. Okay, "Ready, set?' . . etc." First few times ask $S$ if they saw the flickers, then ask them just to tell you if they don't see them.

\section{Discrimination Task: (See Appenäix I)}

Debriefing: "We are finished now. As I told you at the beginning, our interest in this experiment was to see whether your dart throwing could be effected by the subliminal

messages you were receiving. What we plan to do before the end of the term, is to aistribute a form telling you what the hypotheses of the stuay are. We also will tell you the exact messages that you subliminally received. We would prefer to wait until everybody has been run through the study before revealing to anyone what the subliminal stimuli are. Is that alright with you?" If the subject insists on knowing at this time what the stimuli are, reveal them to him and ask him to keep this information secret. 


\section{APPENDIX G}

\section{INFOPMATION ABOUT THE TOURNAMENT EXPERIMENT}

There are many things which affect a person's competitive performance. One important group of factors, we believe, is the way in which people see, and/or remember faint or indistinct expexiences. By experimentally studying this group of factors in people involved in competitive situations we hope to better understand how pexformance may be hindered or improved.

If you decide to participate in this study you will be asked to throw darts at a dartboard, answer some questions, make up short stories, and look at quickly flashed lights which will be words or pictures. From past experience with these or similar procedures we expect no jill effect to you. Also, we expect to learn a great deal about. how competitive performance is affected, which, hopefully, will be useful one day in helping people in various realms of endeavor.

You do nct have to participate in this study, and if you do agree to participate you can still change your mind at any time and withdraw from the study. Your decision to do so will in no way be held against you. This is simply a. research study. All information will remain strictly confidential. 


\section{AFPENDIX \\ CONSENT FORM}

Printed Name of $\underline{\mathrm{s}}$

Fsychology Course:

Section:

VOLUNTARY CONSENT FORM

Name of Experimenter Faculty Sponsor (for students)

Title of Stucy

Farticipation time Credits earned

I freely consent to participate in the study indicated above. I am at least eighteen (18) years of age. To the best of my knowledge I have no physical or mental difficulties which would affect my participation in this study.

SIGNATURE :

DATE: 


\title{
APPENDIX I \\ DISCRIMINATION MASK INSTRUCTIONS
}

\begin{abstract}
"I'm and I'm going to do the next task with you. There's just one more part of the experiment. I have two sets of slides here and I want to see whether you can teil them apart when I flash them at the same speed did earlier. Try as hard as you can because the person who does best on this will win a $\$ 5$ cash prize. First I'll show you four exposures of set A. Then I'll show you four exposures of set $B$. After that I'll show you two sets of four exposures, always four of set $A$ and four of set $B$. Each time I do so, I want you to tell me whether set $A$ was shown first or second.
\end{abstract}

"O.K., if you would put your eyes up against the viewer, we can get started. During this task, please don't look up; keep your eyes focused on the machine. Here are four sxposures of set A (flashes). Here are four exposures of set $B$ (flashes). Now here's the first pair. Here's the first set (flashes). Here's the second set (flashes). Was set A shown first or second?

"O.K., here's the next pair. Here's the first set (flashes). Fiere's the second set (flashes). Was set A shown first or second?"

And so on.

Present the stimuli in the following order:

$A B$

$A B$

BA

BA.

BA

$\mathrm{AB}$

IB

$B A$

$B A$

$A B$

$A B$

$B A$

BA

$A B$

$B A$

$B A$

$A B$

BA.

$A B$

$A B$ 


\section{APDENDIX I \\ TOURNAMENI' EXFERIMENT' DEBRIEFING FORM}

As the experimenter told you, the purpose of the Tournament Experiment was to test whether competitive performance (in terms of dart throwing ability) coula be affected by subliminal stimulation. The messages and pictures you were shown subliminally (or supraliminally for the control group) were designed to arouse certain motivatiors within you which, it was hypothesized, would affect your performance. While those of you in the subliminal condition probabiy were not consciously experiencing these motives during the experiment, it was expected that the messages and pictures you were shown. would affect your performance anyway--for a very brief period of time.

Many psychoanalytically oriented psychiatrists and psychologist.s believe that behavior is greatly influenced by such unconscious motivations and furthermore, that certain categories of uncorscious motivations are likely to be almost universally influential in the behavior of all kinds of people, both psychological.ly healthy and disturbed. In terms of competition, this psychoanalytic approach would predict that unconscious feelings about competing with one's parent of the same sex, as well. as other feelings about one's parents, are important motivating factors which will affect competitive performance in positive or negative directions, depending upon the exact nature of the feelings.

Previous studies conducted at New York University tested this concept using subliminal presentations of messages and pictures. It was found that one stimulus when so presented led to improved dart throwing performance, while one cther impaired performance. In other words, after the presentation of particular subliminal stimuli, dart throwing scores either increased or decreased when compared with a neutral stimulus. More specifically, two stuajies found that compared to the neutral control message PEOPLE ARE WALKING (accompanied by a congruent picture) which was not expected to arouse any important unconscious motives, the message BEATING DAD J.S O.K. (plus a congruent picture) significantly improved dart throwing performance. Similarly compared, the message BEATING DRD IS WRONG (plus picture) significantly impaired dart throwing in two studies. That is, when negative feelings about competition with one's father were activated by the subliminal stimulation, performance dropped; when positive feelings about competition with one's father were stimulated, it improved. 
The Pournament Experiment you were in inciuded a replication of this previous rork and is asking some additional questions. AII of you say the three stimuli described above, and we are precicting that we will find the same results for the subliminal condition as those Fourd in previous research. Everyone also san three "baseline" stimuli. These were included because we wented a measure of your dart throwing ability when you were not shown the other stimuli. The baseline stimuli were: PEOPLE ALE THINKTNG, PEOPLE ARE LOOKING, and PEOLTE ARE STANDING; each waS ShONB with a congrvent picture. The supraliminal conaition according to psychoanalytic theory shoula show no differences, as stimulus input is on a conscious rather than unconscious level. In adoition, we are interested in finding out if the tasks you did before looking into the tachistoscope irifluenced the effect of the subliminal stimuli. Therefore, each of you was rancomly assigned to one of three priming conditions (six groups). Subjects in each subliminal group as well as those in the appropriate supraliminal control group were presented different material (i.e., different questionnaires, ink blots, pictures, and story recall tasks). The previous work always included material designed to arouse the conficts the subliminal messages were supposed to tap (i.e., feeiings about competition with one s father). We therefore included one such group. Subjects in ihis group were given a questionnaire about competition and parents, read a story on this subject, and shown ink blots and pj.ctures supposed to tap feelings about one's parents. Ne are investigating whether the subliminal stimuli will have an effect without prior axousal of this conflict. Therefore, we included two other groups. In one, subjects were shown all neutral material. The other group can be thought of as being in between the first two groups. Subjects were shown some conflictual material (ink blot and pictures) and some neutral material (questionnaire and story). We divicied the material in this way because the ink blot and pictures are more indirect ways of arousing conflicts about competition than are the questionnaire and the story. As psychoanalytic theory hypothesizes that conflicts about competition are active in everyone, we have hypothesized that we will find the same effect of the subliminal stimuli in all groups.

Bacause it was assumed that advanced knowledge of the content of the subliminal stimuli would have contaminated the results, we have not revealed their specific content until now. We appreciate your cooperation in this cricial aspect of the experimant.

For those interested, the results of this experiment will be availabie in. Chaffee 302 with Psychology 113 graduate assistants early in the second semester.

Is promised, cash prizes will be awarded for the top three places in the tournament you were in. Prizes will be mailed to the following people: 
lst place $(\$ 12)$ :

2nd place $(\$ 8)$ :

3 rả place $(\$ 5)$ :

There was a tie for the best pertormance in the discrimination task (telling apart the different stimuli when flashed on subliminally). The $\$ 5$ prize will therefore be split between and

Finally, let us note that it has been the experience with experiments of this sort that for the overwhelining majority of subjects, the effects of the subliminal stimulation last but for a few minutes and then wear away. There have been, however, exceptions in which a rare individual reports that he thinks there may have been a lingering effect. There is a simpie way of dissipating such a lingering effect so that if you feel such may have been the case for you, feel free to contact us. We are also available if you have further guestions about the experiment that you would like us to answer. we can be reached by mail at the Psychology Department, Chaffee Euilding, Kingston, R. I. Rob Harris can be reached by phone in wakefield at 789-1303. Kit Haspel can be reached in Providence at 272-3319. experiment.

Thank you very much for your participation in this

Katherine C. Haspel

Robert S. Harris 


\section{APPENOIX $\underline{\mathrm{K}}$ \\ FFEDBACK FORM}

These headings should be completed by the experimenter before this form is given to the subject.

Name of Experimenter

Fraculty Sponsor

(rox scucients)

Title of Study

This questionnaire is to be completed by the subject anonymously after leaving the experiment, and is to be returned by the subject directly to the Psychology Department office.

1. When I conserted to participate in this study I was told enough about the nature of the study to make an informed choice.

\section{Circle one: Agree Uncertain Disagree}

2. If I was deceived about the nature of this study prior to participation in it, I have now been fuIly satisfied by the experimenter's explanation of the need for this deception. (Check here if not deceived
Circle one:
Agree
Uncertain
Disagree

3. Participation in this study, including the debriefing afterwards, was a valuable educational experience.
Circle one:
Agree
Uncertain
Disagree

4. Participation in this study placed me, personally, under a great deal of stress and discomfort.
Circle one:
Agree
Uncertain
Disagree

5. The debriefing following the study was effective at dealing with any concerns the study raised for me. (Check here if the study raised no concerns for you___, ).
Circle one:
Agree
uncertain
Disagree 
6. I feel I was coercec irto paxtictyation in this experiment by my instructor, who did not allow me any other reasonable options.
Circle one:
Agree
Uncertain
Disagree

Thank you for your help in assuring the safety and value of research participation for future subjects. 


\section{APPENDIX I}

ROOM DIAGRAM

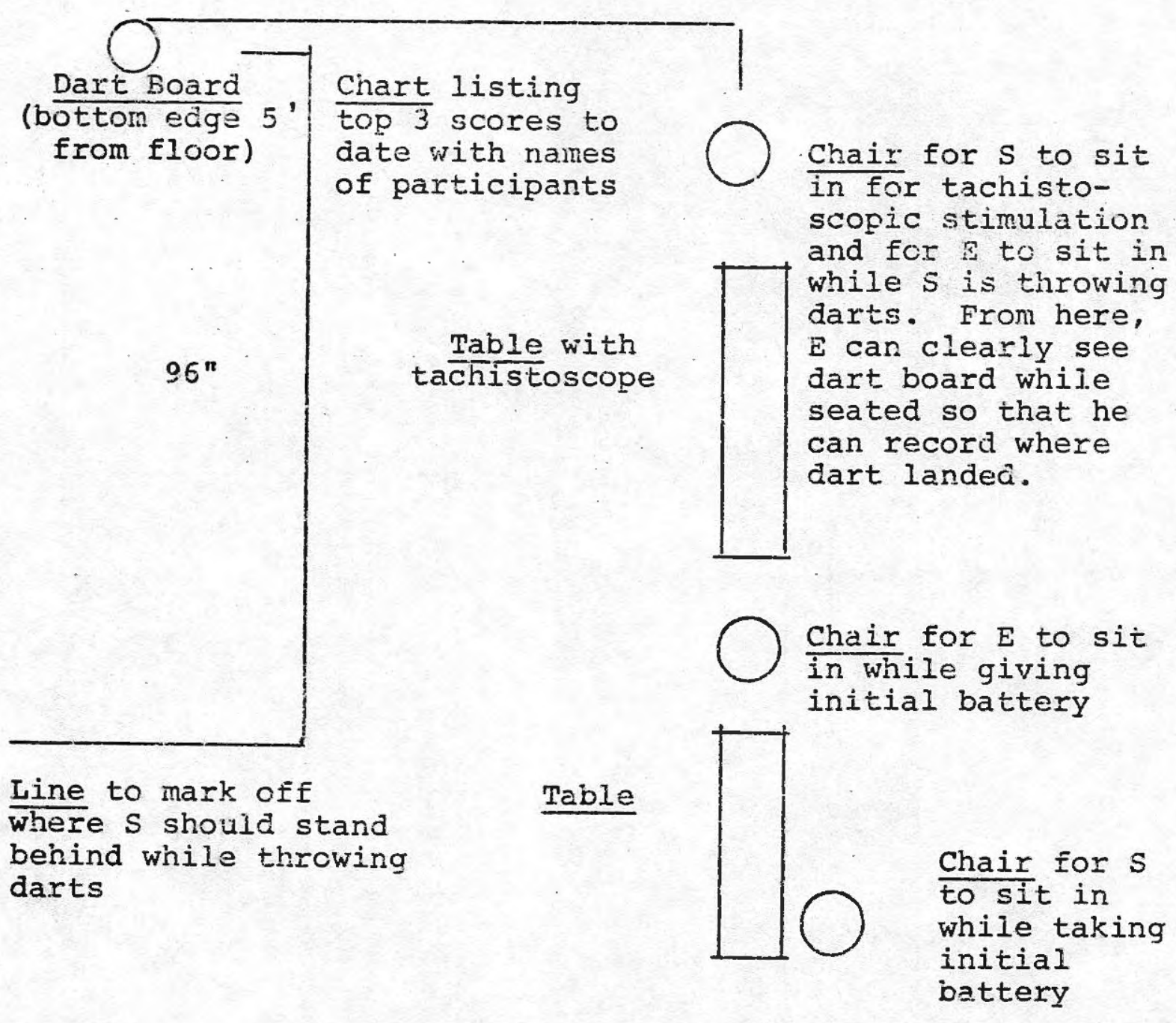




\section{APPFNDIX $M$}

MEANS RND STANDARD DEVIATTONS

OF BASELINE DAR'T SCORES

part I. Full prime (PI)

\begin{tabular}{|c|c|c|c|}
\hline Experimenter & $\mathrm{BF}$ (EI) & $P G \quad(E 2)$ & $P C$ (E3) \\
\hline Baseline $1 \frac{\bar{x}}{\mathrm{~S}}$ & $\begin{array}{l}475.00 \\
121.24\end{array}$ & $\begin{array}{r}435.00 \\
44.35\end{array}$ & $\begin{array}{r}555.00 \\
59.16\end{array}$ \\
\hline Baseline $2 \frac{\bar{X}}{S}$ & $\begin{array}{r}475.00 \\
97.13\end{array}$ & $\begin{array}{r}477.50 \\
92.87\end{array}$ & $\begin{array}{r}520.00 \\
21.60\end{array}$ \\
\hline Baseline $\begin{array}{r}\bar{x} \\
5\end{array}$ & $\begin{array}{r}482.50 \\
91.06\end{array}$ & $\begin{array}{r}497.50 \\
46.46\end{array}$ & $\begin{array}{r}485.00 \\
78.53\end{array}$ \\
\hline
\end{tabular}




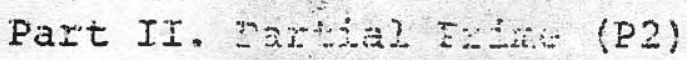

\begin{tabular}{|c|c|c|c|}
\hline Experimenter & $\mathrm{BH}$ (EI) & PG (E2) & $P C$ (E3) \\
\hline Baseline $1 \frac{\mathrm{X}}{\mathrm{S}}$ & $\begin{array}{l}395.00 \\
11.4 .46\end{array}$ & $\begin{array}{l}487.50 \\
134.01\end{array}$ & $\begin{array}{r}497.50 \\
62.92\end{array}$ \\
\hline Baseline $2 \frac{\bar{X}}{\mathrm{~S}}$ & $\begin{array}{r}457.50 \\
29.86\end{array}$ & $\begin{array}{r}492.50 \\
53.77\end{array}$ & $\begin{array}{r}422.50 \\
41.93\end{array}$ \\
\hline Baseline $3 \frac{\bar{x}}{S}$ & $\begin{array}{l}427.50 \\
180.07\end{array}$ & $\begin{array}{r}482.50 \\
99.12\end{array}$ & $\begin{array}{r}460.00 \\
49.67\end{array}$ \\
\hline
\end{tabular}


Part III. Neutral Fine (F3)

\begin{tabular}{|c|c|c|c|}
\hline Experistencer & $\mathrm{BE} \quad(E])$ & $\Psi G\left(E_{2}\right)$ & PC (E3) \\
\hline Baseline $1 \frac{\bar{X}}{\mathrm{~S}}$ & $\begin{array}{l}460.100 \\
139.52\end{array}$ & $\begin{array}{r}45 \% .50 \\
79.32\end{array}$ & $\begin{array}{l}427.50 \\
109.35\end{array}$ \\
\hline Easeline $2 \overline{\bar{X}}$ & $\begin{array}{l}447.50 \\
153.70\end{array}$ & $\begin{array}{r}482.50 \\
54.39\end{array}$ & $\begin{array}{l}450.00 \\
108.63\end{array}$ \\
\hline $\begin{array}{r}\text { Baseline } 3 \frac{\bar{X}}{S} \\
S\end{array}$ & $\begin{array}{l}440.00 \\
192.70\end{array}$ & $\begin{array}{r}520.00 \\
76.16\end{array}$ & $\begin{array}{r}527.50 \\
51.23\end{array}$ \\
\hline
\end{tabular}




\author{
APPENDIX N \\ SIMELE EFFECIS TESTS ON PRIME \\ BY EXPERIMENTER INTERACTION
}

Source $S S$ df MS

$\begin{array}{lrrrrr}\text { Prime at BH }(E I) & 24381.69 & 2 & 12190.84 & 2.22 \\ \text { Prime at PG (E2) } & 14355.46 & 2 & 7167.73 & 1.30 \\ \text { Prime at PC (E3) } & 48533.55 & 2 & 24266.78 & 4.41 \text { * } \\ \text { Erior } & & 142931.05 & 26 & 5492.35 & \end{array}$

* $\mathrm{p}<.05$ 


\section{APPENDIX O}

NEMMAN KE!JYE FEST OF ERTME

AT EXPERIMENTER FC

$\begin{array}{ccc}\text { Partial } & \text { Neutral } & \text { Full } \\ \text { Prime (P2) } & \text { Frime (P3) } & \text { Prime (P1) } \\ 431.09 & 470.94 & 520.84\end{array}$

Partial Prime (P2)

Neutral Prime (P3)

39.85

$89.75 *$

49.90

* $p<.05 ;$ af $(3,26)$ 


\section{APFINDIX F}

MEANS, ADJUSTED MEANS, AND STANDARD DEVIATPONS OF DART SCORES FOR SEQUENCE BY STIMULUS ANALYSIS OF COVARIANCE

Sequence $1(\mathrm{~N}-\mathrm{W}-\mathrm{O}) *$

\begin{tabular}{lrrr}
\hline Stimulus & Neutral & OK & Wrong \\
\hline$\overline{\mathrm{X}}$ & 453.33 & 498.33 & 525.00 \\
$\mathrm{~S}$ & 153.84 & 80.10 & 68.92 \\
$\overline{\mathrm{X}}$ (adj.) & 481.67 & 488.66 & 524.17 \\
\hline
\end{tabular}

Sequence $2(\mathrm{O}-\mathrm{W}-\mathrm{N})$ *

Stimulus

Neutral

OK

Wrong

$\bar{x}$
$\bar{s}$
$\bar{x}(\operatorname{adj}$.

475.00

500.00

486.67

145.29

142.41

476.82

522.15

112.19

510.58

Sequerice $3(W-O-N)$ *

Stimulus

Neutral

OK

Wrong

$\bar{x}$
$\bar{x}$
$\bar{x}(\operatorname{adj} \cdot)$

435.00

133.08

475.00

436.67

455.38

88.71

106.52

452.95

430.53

Sequence $4(\mathrm{O}-\mathrm{N}-\mathrm{W})$ * 
Sequence $5\left(h^{2}-1-0\right)$ :

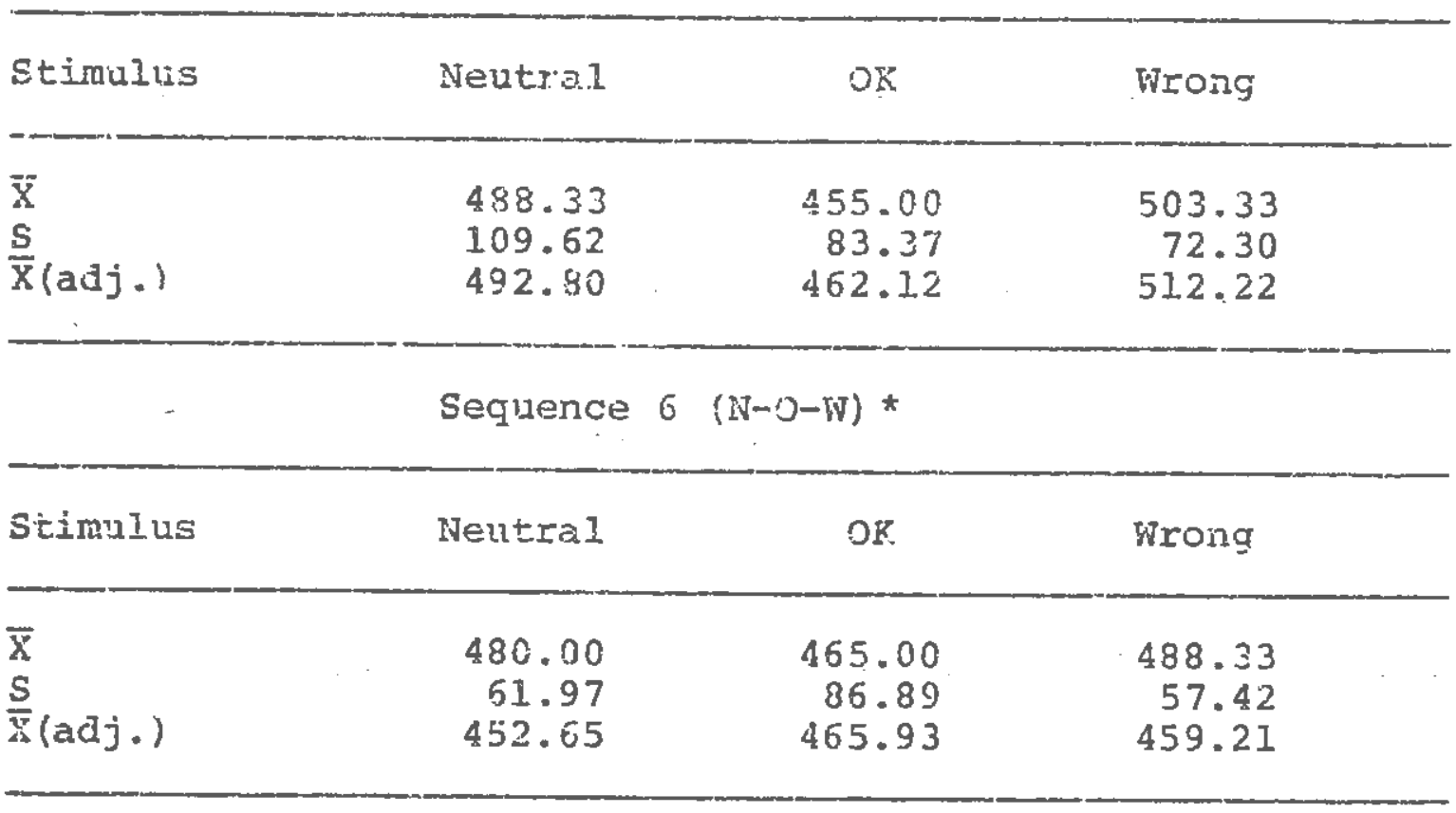

- NoNeutral

$\mathrm{W}=$ Wrong

$\mathrm{O}=\mathrm{OK}$ 


\section{APPENDIX Q}

SEQUENCE BY STIMULUS ANALYSIS OF COVARIANCE

SUMMARY TABLE

\begin{tabular}{|c|c|c|c|c|c|}
\hline Source & & SS & $d f$ & MS & $F$ \\
\hline Between Ss & & & & $\therefore$ & \\
\hline $\begin{array}{l}\text { Sequence } \\
\text { Error }\end{array}$ & (Q) & $\begin{array}{r}65598.94 \\
184913.31\end{array}$ & $\begin{array}{r}5 \\
29\end{array}$ & $\begin{array}{r}13119.79 \\
6376.32\end{array}$ & 2.06 \\
\hline Within Ss & & & & & \\
\hline $\begin{array}{l}\text { Stimulus } \\
\text { QxS } \\
\text { Errox }\end{array}$ & (S) & $\begin{array}{r}3242.81 \\
28811.56 \\
363561.25\end{array}$ & $\begin{array}{r}2 \\
10 \\
59\end{array}$ & $\begin{array}{l}1621.41 \\
2881.16 \\
6162.06\end{array}$ & $\begin{array}{l}0.26 \\
0.47\end{array}$ \\
\hline
\end{tabular}




\section{APPENDIX R \\ STANDARD DEVIATIONS OF DART SCORES \\ COLILAPSED ACROSS LEVELS OF STIMULUS \\ Part I. Prime by Experimenter}

\begin{tabular}{cccc}
\hline Priming Group & FuIl & Partial & Neutral \\
& Prime (PI) & Prime (P2) & Prime (P3) \\
\hline Experimenter & & & \\
BH (EI) & 259.87 & 224.11 & 295.13 \\
PG (E2) & 123.93 & 377.18 & 134.04 \\
PC (E3) & 140.56 & 110.30 & 103.72 \\
\hline
\end{tabular}

Part II. Sequence

\begin{tabular}{ll}
\hline Eequence & \\
$1(N-W-O) *$ & 184.36 \\
$2(O-W-N)$ & 307.79 \\
$3(W-O-N)$ & 277.18 \\
$4(\mathrm{~N}-\mathrm{N}-W)$ & 151.05 \\
$5(\mathrm{~N}-\mathrm{N}-\mathrm{O})$ & 230.71 \\
$6(\mathrm{~N}-\mathrm{O}-\mathrm{W})$ & 161.58
\end{tabular}

* NoNeutral

$W=$ Wrong

$\mathrm{O}=\mathrm{OK}$ 
HEDEAPS

ANALYSIS OF VARIANCE OIT BASELINE DTRK GOMS

BUMMARY TIABLE

\begin{tabular}{|c|c|c|c|c|}
\hline Source & $\$ 5$ & $\approx f$ & $\mathrm{MS}$ & $\underline{z}$ \\
\hline \multicolumn{5}{|l|}{ Setrien SE } \\
\hline Prime (I) & 18161.50 & 2 & 0080.75 & .63 \\
\hline Experimenter (E) & 23057.63 & 2 & 1.1528 .51 & .56 \\
\hline$P X E$ & 25103.38 & 4 & 6275.8 & .86 \\
\hline dror & $52050 \% .39$ & 27 & 1.9278 .04 & \\
\hline \multicolumn{5}{|l|}{ Within Ss } \\
\hline Easeline (S) & 4190.69 & 2 & 2095.34 & .62 \\
\hline $\mathrm{BXX} \overrightarrow{\mathbf{r}}^{\prime}$ & 10636.88 & 4 & 2559.22 & $.7 I$ \\
\hline ExE: & 13509.00 & 4 & 3377.25 & $.5 I$ \\
\hline $1 \mathrm{Bx} P \mathrm{x} F$ & $39779+25$ & 8 & $1972.4 I$ & -44 \\
\hline Errox & 265215.06 & 54 & 4929.51 & \\
\hline
\end{tabular}




\section{GPEGHET T}

ACTUAL AUD GUESSED STQUEACE

OF STIMULI IN SIX DISCRIMIIATION TASKS

\begin{tabular}{lcc}
\hline & Guess lst & Guess $2 \mathrm{na}$ \\
\hline & $\mathrm{A}(\mathrm{OK})$ & $\mathrm{B}$ (wrong) \\
\hline Actual l.st $\mathrm{A}$ & 32 & 28 \\
A.ctua 2nd $\mathrm{B}$ & 30 & 30 \\
\hline & $\mathrm{x}^{2}=.13 ;$ & $\mathrm{df}=1$ \\
\hline
\end{tabular}

II.

Guess ist

Guess 2nd
A (Wrong)
E (OK)

\begin{tabular}{llll}
\hline Actual 2st & $\mathrm{A}$ & 32 & 28 \\
Actual 2nd $\mathrm{B}$ & 30 & 30 \\
\hline & $\mathrm{x}^{2}=.13 ;$ & $\mathrm{df}=1$ \\
\hline
\end{tabular}

III.

Guess lst

Guess 2nd

A (OK) $\cdot$ B (Neutral)

Actual 1st $\mathrm{A}$

Actual 2nd B

36

33

24

27
$x^{2}=.31$
$\mathrm{d} f=1$ 
Actual let H

Aryuzi 2ula B
32

31

$$
x^{2}=0.5
$$

$a r:=1$

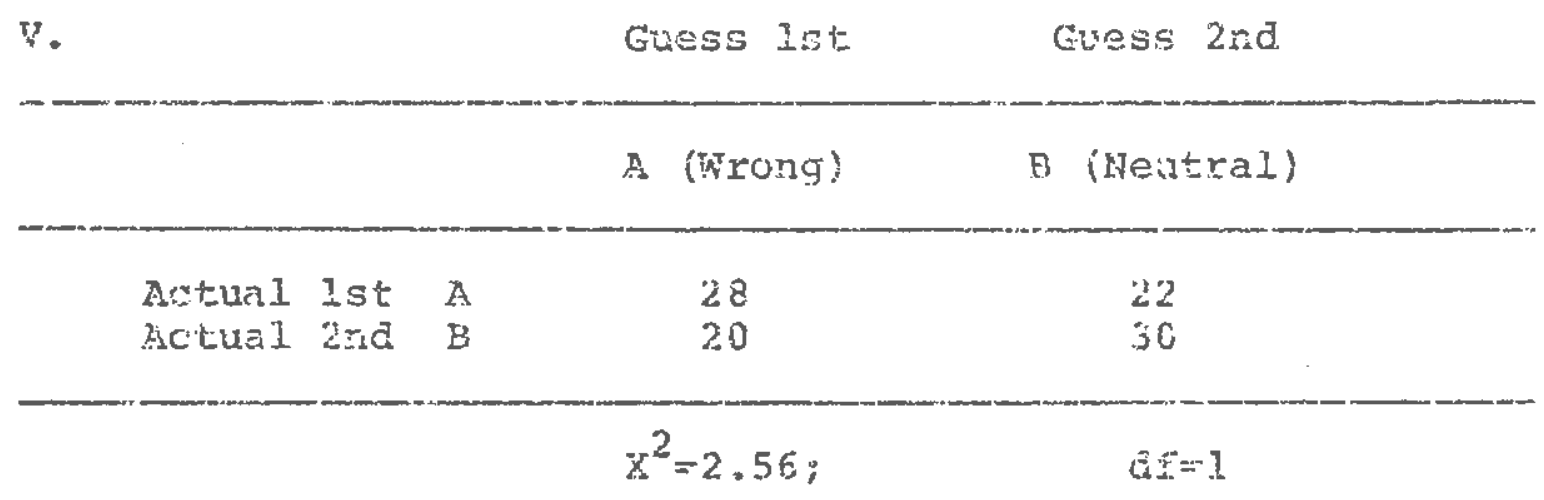

VI。

Guess Ist

Guess 2nd
A (Feutral)
P (iñong)

Actual lst A

Actual 2ra

37
30

33

30

40

$$
x^{2}=1.40 ; \quad \text { af }=1
$$

